Russian literary norm, and even while remaining in principle an ecclesiastic tongue, at the same time it turned out to be a necessary component of the new Russian culture. Without reference to the church tongue it was impossible to achieve correctness, purity, and abundance - those qualities which were to give Russian parity with European languages. It turned out that European beauties blossomed not on distant shores but right here at home, within the churchyard of the Greek Orthodox Slavonic church, any association with which had earlier been forbidden.

As a consequence of this new perception, the church tradition was now considered the preserve not only of pure faith but of pure language. An author unsure of the correctness of his writing or experiencing difficulty in selecting words was supposed to look directly to church books. Insofar as Russian and Church Slavonic were declared to have the same nature, Russian's nature was held to be imprinted in church books; here it was expressed in pure and unchanging form. Hence church books were transformed into a constant standard with which to measure the literary language and which shielded it from the danger of betraying its nature and becoming impure. Lomonosov wrote that "the Russian language will remain in full strength, beauty and richness, firm and inaccessible to change and decline as long as the Russian church will be adorned by singing the glory of God in the Slavonic tongue" (Lomonosov, IV, 230; VII ${ }^{2}, 591$ ). Trediakovskii expressed precisely the same idea: "our Slavenorossiiskii language... can never be irremediably harmed: literary Slavonic will maintain it, preserve it, and save it from injury unwaveringly and for all time." And in another place he wrote that "the Russian language is one of the Slavonic languages, and indeed the most integral (tseleishii) of them, if it hasn't been spoiled; however, nothing will harm it forever: its shield and buttress is our immortal church tongue" (1773, 241 and 372). And so the Church Slavonic literary and linguistic tradition was fully reinstated, and this could not help but have important culturological consequences.

\title{
3. The Synthesis of Cultural and Linguistic Traditions: The Slavenorossiiskii Language and Its Functioning
}

The Petrine linguistic reform and the entire early period of the Russian literary language's formation had rejected Church Slavonic and been based on an anticlerical, exclusively secular notion of the new culture. 
Church Slavonic was perceived as a narrowly church language, and the new literary language was to be the vehicle of specifically worldly, secular culture (see $\S \mathrm{I}-2.1$ ). At the end of the 1740's this conception changed, and the civic language was declared to be based on the ecclesiastic tongue. Of course this change did not mean that the reigning anticlerical cultural conception was suddenly transformed into a clerical one, but nevertheless the change was clearly symptomatic, for had the anticlerical bias remained in force, such a development would have been unthinkable.

The new conception of the literary language put it outside the opposition between clerical and anticlerical tendencies. This was a natural consequence of the fact that the struggle between these two political factions had come to an end. Indeed the cultural synthesis of absolutism presupposed a unified state culture in which both secular and spiritual interests would be subordinated to the all-encompassing and undivided power of an enlightened monarch. Culture became a state monopoly that necessitated its unification into one well-functioning state mechanism, moved by a single aspiration for historical progress and the triumph of reason. The theme of the state, its progress, prosperity, and power, became the main subject of philosophical reflection and it was this that served to inspire both civic leaders as well as poets and preachers. The unity of state-inspired ecstacy was to define cultural unity.

European theories about the enlightened state were founded on a specific cultural mythology whose roots derived from Renaissance attempts to find principles which could organize humanity in a harmony reflecting that of the cosmos. To a significant extent the ideology of enlightened absolutism was a reaction against the failure of the idea of social accord and the harmonious transfiguration of the world that European culture had experienced during the course of the Thirty Years War; the fruits that had been expected of the magic of science and universal love were now, from the mid-seventeenth century, expected to come from the monarch, who was putting an end to religious strife by force and through his unlimited will implanting harmonious concord. The mythological thinking of the Renaissance had undergone a profound transformation, but had not lost its mythological quality.

In the eighteenth century this mythology extended its influence to Russian soil. The realities of communal life, individual spiritual needs, as well as contradictory social and group interests were all relegated to the background in this mythology, and merged into the same class of phenomena as superstition and ignorance and all those things which prevented achieving the ideal. Naturally, historical facts never corresponded to this ideal picture 
in any way. In particular, the reconciliation of church and state in Russia was just as much a fiction as the enlightened monarch. Various priests evaded performance of celebratory services on important holidays (cf. Zol'nikova 1981, 152f), mass defections into the schism continued, and in the upper echelons of the church hierarchy much dissatisfaction continued to fester, rising to the surface in the case of Arsenii Matseevich, one of the few Russian clergymen to publicly oppose Catherine's confiscation of church property (see Popov 1912). The formation of the new cultural consciousness took place in spite of these historical processes, and was itself a historical process of primary significance. A new world view was developing and some reason was easily found to exclude everything that did not fit into it, if only on the grounds that the inappropriate phenomena had to do with people and social groups with which the new culture's enlightened brilliance should not concern itself; and if some unsuitable event did occur, and involve an inappropriate person, he could immediately be consigned to the category of "other," as happened to Arsenii Matseevich, who was transformed from the Metropolitan of Rostov into "Andrei the Liar," and the harmonious picture quickly restored.

The carrier of this new perception was that same "already new people" (Kantemir I, 46) to which the Petrine reforms gave birth and which had assimilated those reforms as its rightful heritage. It was this people which had created the Europeanized culture of imperial Petersburg, and it was in the context of this culture that the conflict between church and state had played itself out. The struggle for church independence ceased to be a cultural phenomenon, as it had been in the time of Stefan Iavorskii and Feofan Prokopovich's clashes, and it was relegated to the status of "unenlightened" protest, the ignoring of which was a most essential part of eighteenth-century enlightenment culture. The changing conceptualization of the literary language described above that demanded a radical reevaluation of the relationship of secular and religious culture permits us to date the formation of this new ideal picture of state harmony to the second half of the 1740's.

The center of imperial Petersburg was the court. It was not only the focus of the new culture's existence in its concrete manifestations, but also the realization of that cultural absolute which was thought of as the motive force behind all cultural development. In the ceremonial life of the court, the religious hierarchy occupied just as central a place as the secular. The culture of European absolutism which the court implanted itself contained a religious as well as secular component. The Empresses' confessor, the heir to the throne's tutor in theology, the court preacher were just as much literary agents of the court as those who composed celebratory odes or academic 
greetings. High offices were filled by those who sought to distinguish themselves in the new field of religious - state oratory. In the 1740's the passion for polemics quitted religious literature, and the age of Feofan's controversial works, the Rock of Faith, the Hammer on the Rock of Faith, and the pamphlet that answered it, Feofan's Insupportable Yoke and Feofilakt Lopatinskii's Supportable Yoke, Markell Rodyshevskii's notebooks, etc.came to an end. The clash of convictions was over, and religious literature became a necessary, even compulsory, component of state enlightenment and the propaganda of absolute monarchy.

In 1767 Catherine the Great and her retinue made a journey down the Volga. During the trip the assembled company took up an unusual occupation for courtiers: they translated Marmontel's Belisarius (1766). The book was well known in Europe. It was simultaneously an admonition to enlightened monarchs, denouncing despotism and exalting a rational concern for one's subjects, and a manifesto of enlightened deism, juxtaposing rational religion to clerical obscurantism. In France the Sorbonne had condemned the book for freethinking, but in Russia it enjoyed another fate. Declaring for all to hear that she was no despot or tyrant, Catherine herself translated the chapter condemning autocratic rule, published the book and had it dedicated to Archbishop Gavriil (Petrov). The dedication was written by Count Andrei Shuvalov, devotee and friend of Voltaire. It said in part:

The ancients preserved the practice of dedicating their works to people whom they sincerely respected. We follow their example, presenting our translation to Your Right Reverence. Your virtues are well known to us, especially the gentleness, humility, moderation, and enlightened piety which abide in you, and which should adorn the soul of every Christian, the more so in a pastor of your rank. All peoples and people of all stations in life need moral admonition. Social happiness depends on the good behavior of its members, and so it is useful to remind them often of the duty of man and citizen, and... to enflame their hearts with the zeal to imitate worthy people who lived before them. Belisarius is such a work... We sincerely admit that Belisarius has captured our hearts, and we are assured that this work will be pleasing to Your Right Reverence, because your thoughts, as well as virtue, are similar to those of Belisarius. (Marmontel' 1768: 1.3-4 verso)

This flattering dedication reads like an imperial edict which expresses the royal conviction that Gavriil's views are similar to Marmontel's. In this way the obligation to profess the worldview which so attracted the Empress was laid upon Gavriil, and together with this, the expectation that he would dress it up in words familiar to the Orthodox ear. He had to assimilate deistic religious toleration (as we have noted, in the context of eighteenth century 
Russian autocracy, religious toleration was not an ideal of religious belief but a practical means of combating church independence). He was to preach civic duty and humbly concern himself with his flock's morality (for more detail see Sukhomlinov, I, 117-25). He was to present a version of Orthodoxy that could be integrated into Enlightenment discourse.

The question of how Gavriil carried out the empress' will and how this conformed to his devotion to Orthodox principles makes him one of the most paradoxical and at the same time deeply symbolic figures of the second half of the eighteenth century. No other eighteenth-century religious writer so consistently carried out a rapprochement between Christian teaching and Enlightenment ideology, asserting the unity of faith and reason, of divine providence and natural right. At the same time, while serving as one of the relgious grandees of Catherine's court, Gavriil remained an ascetic in his private life, and an advocate of monastic endeavor. His brilliant career proceded as if against his will, while his true spiritual desires were fully reflected in his support for monastic revival and a return to the patristic ascetic tradition. His literary works represent only his enlightenment aspect. His sermons and exegetical compositions are marked by rationalism and an emphatic absence of rhetorical embellishments, rare for the day. Gavriil's activity as member of the Commission to Compose a New Law Code and of the Russian Academy speak to his scholarly diligence and keep the mystical, monastic side of his life completely hidden.

Gavriil graduated the Moscow Slavono-Greco-Latin Academy in 1753 at the top of his class, but not desiring to take monastic vows, did not remain there, but requested the job of prosfornik (the one who prepares bread - prosfira or prosfora - for communion), so that he "would have a small bit of bread and always be near a church" (Titlinov 1916, 12-3). The church authorities, however, valued the existence of educated people too highly to allow them individual spiritual exploration. In 1758 Gavriil became a teacher in the Trinity Lavra Seminary and was almost forcibly brought to take monastic vows by the Lavra's Archimandrite Gedeon Krinovskii (for more on whom see below). Gedeon's protection guaranteed Gavriil's swift early rise. Right after his vows he became an hieromonk (ieromonkh) and rector of the seminary, and soon after that deputy (namestnik) of the Trinity Lavra. On August 8, 1761, he was appointed rector of the Slavono-GrecoLatin Academy and Archimandrite of the Zaikonospasskii Monastery. In this capacity he became known to Catherine, who evidently valued his erudtion and his knowledge of European languages (French and German), not all that common among the clergy, as well as his unusual breadth of views. The empress saw in him, in her words, a man who was "sharp and reasonable 
(rezonabel'nyi) and not an enemy of philosophy" (Znamenskii 1875, no. 4, 109). The young archimandrite seemed to Catherine to be a fitting candidate for the role of enlightenened hierarch, whose erudition and toleration would adorn the most liberal court in Europe, and whose strict piety would satisfy the expectations of the Orthodox population.

From then on Catherine herself took a hand in Gavriil's elevation. In 1763 he was named Bishop of Tver, in 1768 member of the Commission to Compose a New Law Code, in 1769 member of the Synod, and in 1770 he was named Archbishop of St. Petersburg and Revel (and simultaneously abbot of the Alexander Nevskii Monastery). Thus before the age of forty Gavriil occupied the most important archbishop's pulpit in Catherinean Russia. On January 1, 1775, he also took over administration of the Novgorod diocese (that was often combined with Petersburg's), and in 1783 was elevated to the rank of Metropolitan. He enjoyed the empresses' good graces all the way until her death, and for all that time was essentially the head of the Russian Church. As P. V. Znamenskii writes, "without upsetting anyone with unnecessary complaints and grumbling over the anticlerical spirit of the age and the violation of church rights, he put all of his energy into strengthening the inner power and means of the church... He strove to raise the moral character and education of the clergy under his care, and organized a Nevskii Seminary... The special object of his attention as archbishop were the monks, in whom he saw the mightiest power of the church" (Znamenskii 1875, no.8, 343).

Whatever Metroplitan Gavriil's private views, in his activity as a publicist he followed the directives of secular power, only modifying them slightly with his own views and tastes. In particular, if we turn to his sermons, we find in them rational moderation, summonses to fulfill one's civic duty, and very little of traditional Orthodox piety. It is indicative that in the foreword to the Collection of Sermons for All Sundays and Holidays, which he published together with Platon (Levshin) on Catherine's orders, it was asserted that "the service of God does not consist only in giving thanks and prayer, and in accomplishing the sacraments... but much more in teaching God's law..." (Gavriil and Platon I: 1. 1). The priority accorded preaching that was declared here (as "moral admonition" needed by "all peoples and people of all walks of life") fully conformed to the rationalist religiosity of the Age of Enlightenment, and is quite far from Orthodox tradition (see § III-1).

The main thing that Gavriil tried to avoid was panegyrical brilliance, and this distinguishes his sermons from the usual homiletic production of the period. A significant portion of his sermons is limited to ethical issues, and sooner resemble moralistic tracts than examples of oratorical prose. This is true even of his panegyrical speeches in which generic requirements 
were less strict, although rhetorical embellishment was one of their generic markers. Thus, for example, Gavriil dedicated the "Speech on Catherine's Name-Day" in 1777 to the theme of hamonizing man's will with God's. He says in it that striving for the common good and for harmony "directly relates to man's perfection... because here both feelings accord with reason and benefit with the benefit of others and intent with God's intent." In resolving the problem of theodicy he argues that "God would not be good if he did not connect bad consequences with bad acts," but he further discusses the impossibility for man to know genuine righteousness given the general imperfection of social life, in which the life of a righteous man "enters into the current of evilly intentioned people." This moralistic sentiment exhausts the speech's theological content. The most important thing for harmonizing man's will and God's is education, which allows people to absorb "the two shortest commandments: love God and your neighbor." Violating the divine order leads to the partial forgetting of these commandments, which "eternity" prescribes. Gavrill further includes a prayer, in which he asks "that we begin this [eternity] here, that the knowledge of this state [divine order] be practical." To this discussion Gavriil adds a few concluding phrases dedicated to the empress. He says that God "entrusted the preservation of his law, and by this our happiness, to our Most Pious Monarch" and that "Her cares, desires and labors" are directed toward the fulfillment of this task (Gavriil 1777, 2f). A panegyric is thus transformed into a moralistic exhortation. ${ }^{47}$

This lowering of style was clearly a conscious choice on Gavriil's part, and suggested a contrast for him between rhetorics and truth. A note was preserved among his papers that probably refers to his work as official preacher and panegyrist: "Forgive me, Most High One, if according to human custom I experienced desires in which my heart took not the smallest part" (RNB, Sobr. Peterb. Dukh. Akademii, no. 422, 1. 1). The mantle of philosopher-hierarch and chcourtier-hierarch appear as a kind of decoration in the grandiose theater of Catherine's empire, summoned to hide and not

\footnotetext{
47 In this context, Sumarokov's evaluation of Gavriil's art of preaching is understandable: "Gavriil, Archbishop of Petersburg, is more a composer of most intelligent philosophical dissertations than of public speeches; because he strives more for dissertation than for rhetorical figures it is impossible to compare him with other preachers. I will only say of him that the beauty of his smooth and imposing style earns fitting praise for his worthy name from the entire enlightened world, and that in posterity he will always be the honor of our age. Gavrill is like a river that fills its banks without noise and by orderly flow, never exceeding its borders" (Sumarokov, VI, 282-3). M. I. Sukhomlinov's judgement that "in his panegyrics Gavriil did not fully evade the rhetorical rut of that time" (Sukhomlinov, I, 103) is only true of a few of his panegyrical speeches which occupy a marginal place in his literary legacy.
} 
reveal the true nature of the actor; this theater pretends to offer a complete picture of reality, and tries to subsume the real life that is taking place beyond its theatrical decorations. For as G. Florovskii writes, "for himself this magnificent and important Catherinean church leader... was a strict man of fasting, prayer, and an ascetic, and not only by intention, but in life" (Florovskii 1937, 123).

In this respect the best description of Gavriil comes from the notes of his cell-mate Feofan, later Archimandrite of the Kirillov-Novoezerskii Monastery (Feofan 1862). Through Feofan Gavrill was connected to the institution of starchestvo and in general to the entire developing movement of monastic renaissance, which he zealously supported. In his wide eparchy he rebuilt monasteries and chose abbots for them from among experienced aescetic monks. He held out for this against the Synod, which opposed his desire to fill these positions with unschooled monks (that is, those who had not had official academic training). In particular, he revived the well-known Valaam Monastery and saved the Moscow Simonov Monastery from closing. He affirmed communal living in monasteries and in 1796 compiled rules for such living, which he distributed thoughout the eparchy. At the same time he sent monasteries the books of Ioann Lestvichnik and Isaac the Syrian, fundamental works of Orthodox asceticism (Pokrovskii 1901, 503-8). With his direct support the Dobrotoliubie (Gr. Philocalia), translated by the elder Paisii Velichkovskii and overseen by Gavriil's order in the Alexander Nevskii and Trinity Lavras, was published in Moscow in 1793. This book more than any other determined the shape of Russian Orthodox spirituality for all succeeding decades. It is this ascetic image of Gavriil that casts a shadow of simulation or ambiguity on his image as an authoritative figure of the Catherinenan enlightenment, as well as on the entire official church culture of Catherine's reign.

This disconnect, this lack of any organic connection between the public and private spheres, not only makes Gavriil's image as sketched out from official sources deceptive, but also applies to Russian enlightenment culture as a whole as created and controlled by Catherine. It appears as a kind of mirage, but an imposed one, demanding the cooperation of everyone who came into contact with it. The church was just as drawn into this as was secular society, forced to find itself a place within the framework of the very same enlightenment mirage. As a result the religious hierarchy battled no longer for the church's independence, as in the Petrine period, but for its position within the state system, while keeping apart, as Gavriil put it, from "useless kicking against the pricks" (Sheremetevskii 1914a, 46). The very same Gavriil, serving on the Commission to Compose a New Law Code, 
achieved his main goal of acquiring special status for the clergy, separate from that of the "middle class" in which craftsmen and merchants were included, and immune to corporal punishment (actually, he only brought this to full completion under Paul). Striving to secure a place in the imperial order and, as possible, to compete with the nobility, the clergy had to assimilate at least the external signs of the reigning noble culture. These signs included, in particular, the new literary language, which had been worked out by the elite educational culture of the nobility. The court preacher had to speak the language, if not of secular society, than at least one that was pleasing and comprehensible to it. The unity of the literary language, having become an attribute of imperial standardization, also became an object of personal concern. In this way took shape the prerequisites for changing the language of religious literature, the merging of a special linguistic register of the literary tradition with the new type of literary language with its aspiration of universality.

\subsection{The Evolution of the Language of Religious Literature}

As we have seen ( $\S$ III-1.2), the changed conception of the literary language did not eliminate its opposition to Church Slavonic, but only modified the character of the opposition. Church Slavonic functioned primarily as the language of church books (Holy Writ and liturgy), in which markers of Church Slavonic were obligatory, whereas in the new literary language (Slavenorossiiskii), also based on church books, markers of Church Slavonic had a definitely optional character and might only appear for special stylistic ends. Thus in theory the language of secular culture was as close as possible to Church Slavonic but did not coincide with it (we are not speaking now of those aspects of the new literary language's normalization in which it was opposed to Church Slavonic, as these did not attract attention in discussions of secular versus religious languages). Having produced a new conception of the literary language, secular culture cleared the way for a cultural and linguistic synthesis of secular and religious traditions, for creating a new literary language as something universal. The language of the reigning culture was no longer that of the Voyage to the Island of Love, but an original synthesis which combined the linguistic heritage of Trediakovskii's novel with that of church books. It was this which aspired to the role of universal literary language for an enlightened Russian monarchy. 
This situation posed a dilemma for religious literature. If Church Slavonic (as it was newly understood) was chosen as its vehicle, the borders between it and the new literary language would coincide with the separation between religious and secular literature. However, if religious literature chose a language which differed from that of church books, the borders between Church Slavonic (again, in the new understanding) and "Slavenorossiiskii" would be based on the opposition between the language of cult and that of culture (the latter combining religious and secular functions). The first solution was associated with clericalism, while the second had ample European precedent - this was the situation in France, and Germany was also moving in this direction in the eighteenth century, even in Catholic areas. Using Church Slavonic in the liturgy and Slavenorossiiskii in sermons and theological writings was analogous to the French having their liturgy in Latin and religious literature in French. Hence it was natural that Russia take the second route.

Most indicative of this development is the history of the language of homilies. Before the seventeenth century the sermon had been practically absent in Muscovite Russia; its place was taken by readings from the church fathers. In the seventeenth century, the Bogoliubtsy (Zealots of Piety) developed the sermon as an important weapon for propagandizing their ideas (cf. Zen'kovskii 1970, 133f), but this Great Russian trend was soon overtaken by sermons of the Ukrainian type. Without a long tradition, the sermon did not become an everyday activity of every priest, as it was, for example, in France and Poland, but a special activity by the learned clergy. In contrast to Vilnius, L'vov and Kiev, where sermons in a language accessible to the local population had prime importance in the battle between the Orthodox and Uniate churches, in Great Russia the sermon might not so much serve the religious enlightenment of the audience as demonstrate the pastor's own sophistication. In any case the sermon was part of educated culture, and for a long time preserved an association with recently introduced scholarly religious pursuits that contrasted with traditional piety.

In these circumstances, it was natural that the language for sermons in Russia be Church Slavonic, and moreover its standard variety, that as a rule revealed the grammatical art of the orator. This was one of the significant factors that preserved the situation in which Church Slavonic served as the single language of culture. In particular, it is indicative that in Moscow Ioannikii Galiatovskii's sermons, written in the Ukrainian "simple tongue," were translated into Church Slavonic (Kharlampovich 1914, 435; Uspenskii 1983, 91). Also written in standard Church Slavonic were Simeon Polotskii's 
sermons that to a significant degree clearly shaped the later Russian tradition of homiletics. $^{48}$

The book of sermons called Statir, written by an unknown clergyman from Perm in 1683-84, eloquently testifies to how this tradition was formed (RGB, Rumiants. 411; about this text, see: Vostokov 1842, 629-33; Sukhominov 1908, 434-8; Alekseev 1965; Uspenskii 1983, 116-8). In the foreword to the book, the author writes that the educational works available at this time were too complex for his provincial audience. This refers both to traditional translated works (for example, the sermons of St. Ioann Zlatoust [John Chrysostom]) as well as to new and original ones (for example, those of the highly esteemed Simeon Polotskii). Zlatoust's writing was "very incomprehensible, not only for the audience but also for those [priests] who read him, because the people who live in this area [are] very simple; not only laymen, but also clergymen, regarded Zlatoust's writing as if it were composed in a foreign language" (1. 5 verso) Similarly, "the language of the Obed and Vercheria [books of sermons] by the industrious and most wise Father Simeon Polotskii sounds like the height of erudition to the least educated people and is not understood by those rude in reason" (1. 5-5 verso). At the same time, linguistic analysis of the author's own language shows that he makes no conscious deviations from traditional Church Slavonic usage (Zhivov 1991). He consistently uses simple preterits, in proportions typical for traditional as opposed to hybrid usage, and tries to avoid the variativity characteristic of the hybrid language, although he is unable to normalize his language in accord with the standard grammatical approach. At the same time, there are no grounds for connecting his declarations about "simplicity" with the elementary nature of the author's sermons, either in terms of their rhetoric or content, as do Sukhomlinov and Uspenskii (Sukhomlinov 1908, 437; Uspenskii 1983, 117). The author's desire for simplicity and accessibility remains declarative, motivated by the fact that he does not feel himself capable of fully reproducing the learned, bookish language in which books are published in the capital. "Simplicity" here serves as just another way of describing the author's relative lack of education. [...] It is all the more indicative that he considers it necessary to write in the

48 This is suggested in particular by the specific statistical distribution of new and old endings of $o$-declension nouns in plural oblique cases (the greatest number of new inflextions in the instr. pl., the least in the dat. pl., with the loc. pl. occupying an intermediate position) that are found in Simeon's sermons and then repeated in homiletic literature for more than half a century. The adoption of such practices may only be explained in terms of specific written routines tied to a particular genre, when one cohort of preachers reads and assimilates the linguistic properties of texts created by the previous generation (see Zhivov 1993, 95, 103; Zhivov 1995, 74-7). 
standard bookish language, and sees his own work as an innovation oriented on educated models. Indeed the very idea of preaching rather than reading from the Prologue ${ }^{49}$ was perceived as a novelty that came into conflict with traditional piety. The author tells how he got the idea of compiling a book of sermons: "I heard how in Russia in many cities very wise clergymen recite sermons (poucheniia) that they improvise on their own (ot ust) and do not read from books, and people very happily listen with great amazement. For Kiril Stavromeniiskii ${ }^{50}$ in his book praises oral teaching very much, although because there are so few wise teachers in the church people are forced to read aloud from books. Thus I took him as a model, wanting to attract listeners..." (1. 5). The author was clearly attracted by the new phenomenon in Russian religious life, ready to follow the example of the Ukrainian author and to see himself as an innovator. This innovation led to clashes with his congregation and with other clergymen, in part recalling the persecutions to which Ivan Neronov and Archpriest Avvakum had been subjected in their day. To describe this conflict a different imaginative framework was selected - the opposition of knowledge and ignorance, enlightenment and error. [...] Thus at the end of the seventeenth century a preacher could only act as a reformer, entering into confrontation with the ignorant mob.

Insofar as homiletics was an educated innovation, the language of sermons necessarily had to be Church Slavonic. The voices that called for the comprehensibility and accessibility of religious pedagogical texts in the second half of the seventeenth century had in mind not an opposition between Church Slavonic and Russian, but between rhetorically adorned language (in sermons made complex by Baroque "concetti") and language without such adornment ( $(0-5)$. Several times St. Dimitrii Rostovskii finished his sermons with an apostrophe to his unlettered listeners, offering them a special additional statement which presents a summary of the moral of the sermon. In one of them he says: "I think that not everyone will be able to keep what I have said in their memory (pamiatstvovati) except for the learned (kniznyi); the simple and unlearned will go away without benefit. So I will say something for them worth keeping in memory in a way they will understand (pamiati dostoino)" (Dimitrii Rostovskii, I, 1.51 verso). Analogously, in a sermon on August 19, 1701: "It is already... time to end with an 'Amen'... but... I think... that everything I, a sinner, have said was not intelligible to the unschooled, and I fear they will go away without profit, and I do not want to

A collection of saints' lives and edificatory stories geared to the church calendar. (Translator's note)

50 The author of the Statir evidently had in mind Kirill Trankvillion-Stavrovetskii and his Uchitel'noe evangelie. 
appear as a bombastic orator but as a useful teacher, so I will say something short for the profit of the simplest people" (ibid, V, 1.56 verso). After these statements follow texts in correct Church Slavonic, stripped, however, of Baroque rhetorical devices. Thus standard Church Slavonic remained the basis for homiletic practice.

The situation changed during the Petrine period, and is connected first of all with the activity of Feofan Prokopovich. After Feofan's move from Kiev to Great Russia the language of his sermons gradually changed from standard Church Slavonic to hybrid (for more detail, see Kutina 1981 and 1982; Zhivov 1985a; cf. § I-2.2). In his language appear variations in the inflection of nouns and adjectives, as well as variations in lexical and morphonological correlatives; dual forms disappear (except for lexicalized ones); the use of aorist and imperfective is lessened; participles lacking in agreement (gerunds) appear; syntax is simplified, etc. — all of which are characteristics of hybrid Church Slavonic. But however powerful the process of simplification may have been, the language remained Church Slavonic, which is unquestionably attested by the same simple past tense forms, by the use of active participles of the tyре видяй, изволивыци, by the use of dative absolute, and so on. Having assimilated hybrod Church Slavonic as the main language for his sermons, Feofan subsequently moved to a less refined variety of that language, away from one in which, in particular, simple preterits were used relatively often and remained the principle means of expressing the past tense, to a language in which these forms only occurred occasionally, and only when motivated by theme or composition.

The movement toward comprehensibility and simplicity which Feofan clearly instigated did not, however, take the sermon beyond the realm of Church Slavonic, and the fact that it was used consistently in sermons was fully conscious. Feofan actually could have written in the "simple" (i.e., not Church Slavonic) language; for him the "simple" language was connected with the absence of those very marks of bookishness he preserved in the sermons (see the discussion of his editing of the History of Peter the Great, $\S$ I-1.3). For Feofan standard Church Slavonic, hybrid Church Slavonic, and the "simple" tongue were functionally distributed — standard as the language of cult and scholarly theological tracts, hybrid for sermons and religious literature aimed at a wide audience, and the "simple" as the language of secular literature (see Zhivov 1985a, 78-81). One cannot help but see in this division a realization of the opposition of civic and secular that was a basic element of Petrine cultural policy (§ I-1.2).

This functional distribution of languages that was certainly quite purposeful clearly demonstrates that the Slavonic grammatical elements in Feofan's sermons were not the accidental vestiges of the former tradition 
but, on the contrary, quite intentional, placed in the text to define its linguistic register. It is therefore methodologically incorrect to consider these determining markers of bookishness on the same level as variations that are irrelevant for defining the language such as mixed endings in noun declensions or pleophonic and non-pleophonic forms. Each sermon must be analyzed as a whole (excluding quotations), and not as fragments, and in this whole the first task is to identify the markers of the linguistic register. Otherwise even the most detailed linguistic analysis may lead to mistaken results. ${ }^{51}$ Thus L. Kjellberg, analyzing a fragment of Prokopovich's sermon of March 1, 1725, writes: "In this specimen of pompous rhetoric the language is not yet free... of the heavy dross of Slavonic. Aorists and imperfects have disappeared in favor of preterits in -л-, but auxiliary Slavonic words like аки and паче are kept as well as participles of the type раждмій and сылй with which the language is riddled. It is true that one finds a Russian ending in the dative pl., in по льтам, but the regular Slavonic inflection in добріи Россійстіи сынове" (Kjellberg 1957, 14). Yet simple preterits are encountered in the sermons as a whole. A piecemeal examination and lack of discrimination between relevant and irellevent markers for distinguishing linguistic registers leads Kjellberg to characterize Prokopovich's language as "Russian with distinct Slavonic contributions" (ibid, 18). A differential analysis supports L. L. Kutina's conclusion that the language of his sermons is "simple Slavonic" (see Kutina 1981, 44; Kutina 1982, 8).

It is possible that it was directly due to Feofan's practice that the language of Russian sermons after the 1730's (or even somewhat earlier) became hybrid Church Slavonic. Although the concrete material remains almost completely unexamined from a linguistic perspective, selective analysis indicates that in all sermons of the period there is a definite merging of genetically Russian and genetically Church Slavonic elements in areas which are neutral insofar as the juxtaposition between the bookish and nonbookish markers is concerned, and at the same time, a series of marked Church Slavonic elements used to demonstrate bookishness place the text within the bounds of Church Slavonic (see $\S 0-2$ ). The mechanism used to create texts in hybrid Church Slavonic allows for a high degree of variability, both on the level of the concrete correlation between marks of bookishness and the neutral background, and, within the framework of this neutral background,

Such an approach, which in addition substitutes general impressions for concrete analysis, results in the kind of crude and improbable description that we find, for example, in E. Budde, who writes that "Feofan Prokopovich ... despite his religious rank, wrote and gave sermons in an almost conversational Russian" (Budde 1908, 50). 
also on the level of the relation between grammatically normative and nonnormative, old and new forms. This is also evident in the sermons of this period. Indeed, among them one encounters those in which marked Church Slavonic elements (markers of bookishness) occur in almost eveny sentence, as well as those in which such elements only occur occasionally, in a few cases, functioning not as a regular grammatical feature but as the semiotic marker of register.

I will cite several examples. I will begin with Dimitrii Sechenov's sermon on Annunciation, 1742. The use of the aorist and imperfect in this semon is constant and not connected with any definite thematic, compositional or stylistic purpose, cf. ожидаху, желаху (Dimitrii Sechenov 1743, 4); aorists откыся, познася (3); видъ сльиша, видъша, прїиде, бысть, явися, избра, дарова, созда (4); видъ (5); содбла (7); избавлени быхомъ (12); etc, The $2^{\text {nd }}$ pers. $s g$. л-forms are used with copula, i.e, are regular perfective forms: сподобилася еси (8), даровала еси, насльдовала еси (11). Notably, л-forms make up only somewhat more than $50 \%$ of all past tense forms, that is, significantly less than in Feofan's later sermons. Present participles of the type изволяй (6) and творяй (7) are encountered. Specific features of bookish language appear such as relative clauses with иже: ихже око не видъ (5) иже созда (8). Exclamations are used as a constant rhetorical device, and the exclamatory genitive regularly occurs, е.g., О несказанныя Божїя къ человьку любви! (4), О чудесе новаго... (9). The dative absolute is also met: церьковъ Россійская... прославлялася, братїи нашей православнымъ хрїстїаномъ подъ рукою агарянскою и еретическою сущимъ... (12) For the functioning of the aorist as a mark of bookishness (lacking in properly grammatical significance), its use in a series of coordinated verbal forms together with л-forms is indicative, $\mathrm{cf}$. the sequence of coordinated verbs like погубиль, отдася, подпаде, огорчиль, прогнъваль, попраль, попралъ, презрбль, вмъниль (5) ог собралъ, вручи (12), etc. There also occur variations according to non-relevant markers. Instr. pl.: усты (4, 10), съ скоты, звбрьми, и гады (5), дъльл (12), надъ враги (12), дарами (10), трудами (16). Prep. pl.: печальхъ (10), ушесъхъ (13), по мракахъ (4), ущерббахъ (11). I will also mention a pleophonic form: головы поотрубали (16), although non-pleophonic forms are the norm. To varying non-relevant indicators belong infinitival markers: сказать (3), видђти, пожити, изчислити, измьрити (4), быть, описати (5), знать (9), истребить, испразднить, отгнать (13), etc. These variations clearly are not accidental mistakes, but indicate the hybrid language of the 
sermons. ${ }^{52}$ The same variability of the hybrid language may be seen in Kirill Florinskii's speech on Empress Elizabeth's birthday, December 18, 1742 (Kirill Florinskii 1741; cf. Kjellberg 1957: 15-16).

Amvrosii Iushkevich's sermons are of another kind. Marked Church Slavonic elements are limited to a very small number and play a purely symbolic role. As an example, I will analyze his sermon on the interment of Anna Ioannovna of December 23, 1740. Of the relevant markers, imperfects are completely absent. Aorist forms are only used in four cases and are motivated by standard contexts for internment speeches: [Импратрииа] отыде въ горнюю къ Отиу Небесному обитель (Vnutrennii byt, I, 479), благоутробія мати ваша скончася, тріумфальных побъдъ вашихъ лаври и торжествъ россійскихъ вънць мразомъ смерти увядоша (480), столпь крбпости оть лица вражія разрушися (480). Forms of the $2^{\text {nd }}$ pers. sg. perfect with copula occur several times: погружаль еси (двоеглавый орле) (480), превозносилася еси (481), наказаль еси (482), утьииль еси (483), опечалиль еси (483), определиль еси (483). ${ }^{53}$ Together with relative clauses with который, clauses with иже are also used: всепресвътльйшее солние твое, въ немъ же збниць твоя погружаль еси (480), императора Іоанна, его же въ въчномь совъть опредблиль еси иарствовать надъ нами (483). In one place a striking syntactical Grecianism is used, a construction $я к о+$ infinitive in the function of a consecutive subordinate clause: ...u толико победами благополучными, прославилась, яко исполнится на ней словесам Духа Святого (481; cf. Issatchenko 1980, 87). A genitive of exclamation occurs several times: $О$ вьсти печалнбйшія! (479), O прежесточайшія и неуврачуемыя язвы сердець нашихь! (480). In the sphere of markers not relevant for juxtaposing languages there is significant variability: dat. pl.: монастырямъ (479), словесамъ (481), врагомъ (480,

52 Only unfamiliarity with the language of homiletic literature and lack of linguistic background may explain G. P. Blok's assertion in the commentary to Lomonosov's "Gimn borode" [Hymn to the Beard] that "Dimitrii's style of oratory, close to conversational language, often fell into the most vulgar popular speech" (Lomonosov, VIII², 1076). The example of "vulgar popular speech" cited from Sechenov's sermon - "слово отрыгнем Царице Матери" (Lomonosov, ibid; Dimitrii Sechenov 1743, 12) — strikingly illustrates the arbitrary nature of attempts to characterize linguistic elements based on modern notions of vulgarity. This phrase is a quotation from the first line of the first song of the canon for Annunciation, and отрыгнем is a normal Church Slavonic verb that has no popular connotations whatsoever (see Sreznevskii, II, col. 767; SRIa, XIV, 24-5). In the last analysis, Blok's statement was shaped by the grouping together of "indecent" and "popular" which derives from French purism of the mid-eighteenth century and has no connection at all to Sechenov's language (cf. § III-1.3). [...]

53 The last four examples are not very significant insofar as they are used in address to God and may thus be seen as a marker of prayer within the sermon, that is, they function as a kind of specially marked "alien speech" that deviates from the usual texture of the sermon. 
483). Instr. pl.: громами (480), падежами (480), съ... грады (480), дъль (481). Adjectival endings, normative for Church Slavonic, are relatively stable, although despite the dominating gen. sg. fem. ending -ьъя/-ия we find оть которой (482). In general, infinitives in -ть are used (печалиться [479], плакать [480], прославлять [481], etc.), although there are also infinitives in -ти (свидътельствовати [481], исполнитися [481] ). Short active participles are used without agreement (as gerunds), moreover together with the neutral affixes $-a /-r$ and $-в ш и$ are met the specifically bookish -вmе; thus with a sg. masc. subject потерпввше (479), sg. fem. оставя (479), бывше (482), пріобретше (482), въдая (482); pl. видя (483). Forms of the vocative are used rather consistently (орле [480], граде [480], невьсто [480]), although the nominative may also occur in address (иерковь [480]).

The same linguistic features appear in Amvrosii's sermon on Empress Elizabeth's birthday, December 18, 1741, although the proportion of marked Church Slavonic elements is smaller and the proportion of genetic Slavonicisms among non-relevant markers is noticeably larger. In this rather lengthy text forms of the aorist are encountered only three times, at the start and ending of the sermon: тогда прїиде Давїъ (Amvrosii Iushkevich 1741, 4), но не восхотьхъ ему ни единаго зла сотворити (5), яко рука Господня укрбпи мя (16). Forms of the $2^{\text {nd }}$ pers. sg. perfect with copula appear only in the prayer concluding the sermon: дароваль еси, обрадоваль еси (16). Genitive of exclamation occurs several times: О нашего неблагополуия! (5), О радости! О торжества несказаннаго! (12). Иже - constructions are not encountered, and an active participle occurs one time (владъй [6]). One might possibly consider the pronouns тя (3), тебе (acc., 4), ю (16), etc., as marked Church Slavonic elements (although the first person personal sg. pronoun is only $я$ ), and one could also include here functional words of the type аще, ово... ово, etc. Indicators of the Church Slavonic register proper are limited to these. In the sphere of non-relevant markers we find broad variablilty and it involves all noun inflections. Thus, for example, instr. pl. грбхами (3), образы (4), врагами (5), дълами (7), потомками (7), дарами (7), трудами (7, 12). словами (7), солдатами (12), потомками (13), претекстами (14), печальми (4), учительми (9), родительми (9), еtс. In adjectival endings in the presence of the stable -аго/-яго in gen.-acc. sg. masc. and neut., in the nom.-acc. sg. masc. occur the variation: который (3, 11), истинный (3), дикой и незнаемой (7), Россійскій (7), Россійской (8), морскій (7), неславный (9), темный (9), иностранной (13), незнаемой (13), etc. The same with gen,. sg. feт.: живыя (4), всякїя (4), своея (7), последнбй (7), всякой (9), самыя блаженныля (9), etc. Infinitival forms are just as variable: толковать (3), запамятовать (3), сыскаться (3), сказать 
(3), взяти (4), воспитати (4), научити (4), мстити (5), удивлятися (5), владъть (6), забывать (7), промышлять (8), etc. Lexical morphological markers also vary, for example, pleophonic and non-pleophonic forms: здравїе (4), главы (4), гласы (6), головами (10), голову (13), глада (13), гладомъ $(13,15)$, кратко (13), головы $(15)$, etc. $^{54}$

These more or less contrasting examples may serve to demonstrate the linguistic heterogeneity which hybrid Church Slavonic demonstrated in the homiletic literature of the 1730's and 40's. As far as I can judge from the material with which I am familiar, marked Church Slavonic elements which indicate the linguistic register of the sermons are universally attested, as are variations in the sphere of non-relevant indicators. The proportions, however, fluctuate, and these fluctuations describe a weakly differentiated continuum whose diapason was suggested by the examples we analyzed. It is possible that certain lines of continuity will be able to be isolated, and that the choice of this or that type of hybrid Church Slavonic will be shown to be more than simply fortuitous. This, however, requires special research. Together with the extreme cases, one may also cite many examples of an intermediate character.

To such intermediate texts belong, for example, the sermons of Grand Prince Peter Fedorovich's tutor in Divine law, Simon Todorskii. In his sermon on the occasion of the Grand Prince's birthday on February 10,1743 , we may observe a relatively high proportion of marked Church

54 In principle, the concentration of the basic markers of bookishness at the start and end of a work and their almost complete absence in the middle allow us to see it as bilingual. In this case one may consider what is happening in Amvrosii's sermon as switching linguistic codes, hybrid Church Slavonic alternating with Russian (which is significantly Slavonicized in the sphere of non-relevant markers). Church Slavonic is used at the beginning and end of the sermon, where the Biblical story of David and Saul is presented, and which includes a general moral teaching and a prayer addressed to God. Russian is used in the middle, where the history of the recent palace coup that brought Elizabeth to the throne (on November 25, 1741) is told, and from the perspective of an eyewitness. The change in the narrator's position may be seen to motivate the change in linguistic code, a mechanism that is known in literary monuments of the sixteenth and seventeenth centuries (see Uspenskii 1983, 46-9; Zhivov and Uspenskii 1983, 162-4). The complex character of this text led L. Kjellberg into error (1957, 18). He characterizes Amvrosii's language as "Russian with weak Slavonic contribution" and asserts (as the material above indicates, without sufficient basis) that "Amvrosii speaks the normal Russian literary language of his time; it hardly includes more Slavonicisms than that of secular writers of the same epoch" (16). As we have shown, in the given era neither Lomonosov nor Trediakovskii used Church Slavonic elements as markers of linguistic register, while in the sphere of non-relevant markers there was significantly more normalization by the late 1730's than we see in Amvrosii. Amvroisii's later sermon on Elizabeth's coronation of 1743 (Amvrosii Iushkevich 1744) testifies to his lack of interest in reformed ideas on language. While the dominant form of expressing the past tense here is the $\pi$-form (more than $80 \%$ ), fairly common simple preterits unambiguously indicate hybrid Church Slavonic. 
Slavonic elements on the background of rather broad variations in the sphere of non-relevant markers. In a series of cases we meet imperfectives: смиряху (Simon Todorskii 1743, 6), озлобляху (6), бываху (6), насильствоваху (6), укрвпляхуся (6), освьтише (11), предлагахъ Его Высочеству (14). Aorists are also used: пристави (6), рече (7), бысть (17), якоже вкраиъ показася (17). I also note the pronoun яже (9), the participle сый (12), and the athematic declension имамы рещци $(6,10)$. The variativity of the neutral background material is clearly reflected in noun declensions: dat. pl.: неправедникамъ (3), кедрамъ (4), дъламъ (6), праведникамъ (6), сыномъ (6), княземъ $(8,9)$, лииамъ (8), бъсомъ (11); cf. also in the coordinated constructions неправедникамъ, ябедникамъ, донощикамъ и безсовъстнымъ представителемъ (7), дътемъ и насльдникамъ (8). Instr. pl.: зубы (4), обрядами (5), регламентами (7), указами (7), титлами (11), съ Кабинеть-министрами и Генералами Фельдмармалами (12), неудобствами (13), резонами (14), сvмволами (15) (the ending -ами is close to the normative). Prep. pl.: туманах (3), дворьхъ (4), дъльхъ (6), глазахъ (7), насльдникахъ $(8,13)$, праведникахъ (8), дълахъ $(9,10)$, льтахъ (11), судъхъ (11), репортахъ (14), государствахъ (14). There is a similarly strong variability in infinitival markers: уязвити (3), потрафить (3), заклати (4), повредиться (4), множитися (4, bis), искоренити (4), признать (4), умножати (4), сохраняти (4), изъимати (4), etc. Cf. also in parallel constructions: уничтожать и искореняти (8), наставити и обучить (8). Short participles are used without subject agreement, cf. with sg. masc. привыкнувши (8), возлюбивши (9), with pl. устрашаяся (7), шествуя (9), etc. $^{55}$

This sort of data allows us to assert that the introduction of hybrid Church Slavonic into homiletic literature by Feofan Prokopovich (together, evidently, with Gavriil Buzhinskii) created a tradition that was followed by later religious orators. This new tradition clearly had both cultural-linguistic as well as literary motives. Among the first include the status of the hybrid language itself. On the one hand this was a special ecclesiastic language which

The proportion of marked Church Slavonic elements is even higher in another of his sermons, on the marriage of Petr Fedorovich and Catherine, presented on August 25, 1745 (Simon Todorskii 1745). Here is some data on the markers of bookishness (in the sphere of nonrelevant markers the picture is more or less analogous to that of the sermon of 1743). Here we find aorists: избра (5), бысть $(5,10)$, благослови (5), рече (7), возвысися (5), умножишася (5), возревноваша (5), прїдоша (6), рьша (6), спаде (7), возлюбленъ бъ (8), выну бъ сходящее (8), остави (13); and a perfect with auxiliary verb: подвигнулся есu (7). On the whole, forms of the imperfect, aorist and perfect with auxiliary make up more than $26 \%$ of all past tenses. I also note the forms: азъ Россїянинъ сый (9), имамы рещи (8), еже речено бысть $(10)$, егда $(4,9)$, аще $(3,10)$, абїе (11). 
was juxtaposed to the language of worldly literature which was perceived at the time as specifically secular. On the other hand, the hybrid language, as already noted ( $(0-5)$, was the closest thing to a candidate for a popular, accessible language that still maintained its connection with the religious literary tradition. We should recall that during this period the sermon still belonged primarily to cathedrals and churches of the capitol cities, and that their audience mostly consisted of representatives of the new secularized culture, that Europeanized nobility which, according to Sumarokov's testimony, called church books "not Russian" $(1748,7)$. Therefore the choice of the hybrid language might have been conditioned by the desire to at least partially cater to the linguistic tastes of the audience.

The literary tradition that arose in this context was directly modeled on Prokopovich's sermons. One may find direct echoes of his images, rhetorical structures and themes in the most diverse preachers of the epoch, for example, in Amvrosii Iushkevich when he enumerates Peter the Great's achievements (Amvrosii Iushkevich 1741, 7-9; cf. Feofan Prokopovich I, 111f; II, 147f.), or in Simon Todorskii, when he alludes to Prokopovich when he says that the ancient pagans would have considered Catherine a goddess (Simon Todorskii 1745, 10; cf. Feofan Prokopovich, II, 140) or writes that Elizabeth "was as close to death as the cannonball which fell at her feet" (Simon Todorskii 1745, II - an allusion to the well-known image of Peter's hat with the bullet hole in Prokopovich's "Sermon on the Battle of Poltava" of 1717 - Feofan Prokopovich I, 158; see the quote in $\S$ I-2.2). New linguistic or historical and cultural stimuli were needed to shake the authority of a tradition which had become so well established.

Such stimuli appeared in the 1750's, when the struggle against clericalism was no longer relevant, when the reigning Europeanized culture had asserted a monopoly over enlightenment and the Russian literary language was reconceptualized as "Slavenorossiiskii," standing in the closest possible proximity to "the church language." The possibilities for homiletic literature which this new situation opened up were first grasped by the young monk (ierodiakon) and student of theology at the Moscow academy Gedeon Krinovskii. Thanks to his eloquence he was appointed court preacher on January 8, 1753, when he was not yet 30 .

Gedeon's brilliant career was rather unusual but very indicative of an era when the ability to grasp the latest cultural fashions and put them into action could open up the way to the highest positions in capital society, a society as yet without fixed traditions and eager to accept and follow those adept in expressing new ideals and cultural prescriptions. After he graduated from the seminary in Kazan, Gedeon took monastic vows and remained there 
as a teacher. In 1751 he left Kazan for Moscow, where he was able to enter the Moscow Academy. As a student there he attracted attention as a preacher. He was appreciated by I. I. Shuvalov, who recommended him to the Empress. His appointment as court preacher was the first step in his quick ascent. In 1758 be became member of the Synod and almost immediately thereafter archimandrite of Russia's leading monastery, the Trinity-Sergius Lavra. In 1761 he was ordained Bishop of Pskov and gave up his post as court preacher. In 1763 he took sick while on the road to Pskov and died on June 22 (see: Titov 1907; Seremetevskii 1914). P. V. Znamenskii describes Gedeon as "a lively and emancipated monk, and a court one as well, obliged for everything to the secular power which had so elevated him above his brethren.. And he lived like a grandee" (Znamenskii 1875, no. 2, 106). Toward the end of his life, Gedeon, despite his youth, was probably the single most influential church hierarch. The two most important church figures of Catherine's reign, Petersburg Metropolitan Gavriil Petrov and Moscow Metropolitan Platon Levshin, both owed their early advancement to his patronage.

Gedeon's first brilliant steps were tied to his sermons. How did he transform the sermon to ensure himself such success? Today's reader will not be struck by his sermons' absorbing presentation, depth of thought, or heightened spirituality. But for his contemporaries Gedeon's style was distinctly different from the rhetorical embellishments of previous religious orators. Platon Levshin wrote that it was as if his listeners "were beside themselves and were afraid that he would stop speaking" (Seremetevskii 1914, 325). Sumarokov also considered Gedeon deserving of praise (VI, 281). ${ }^{56}$ P. V. Znamenskii writes: "Society was pleasantly struck by his new ways, which were so completely alien to the methods of the old, Kievan school, and all those rhetorical ornaments and conceits of argumentation, comparisons and tropes... which strike one so unpleasantly in the speech of previous preachers, not excluding... Feofan Prokopovich. His clarity and simplicity of thought, lively fantasy, precise and simple style which were accessible and comprehensible to the least educated listener... captivated his entire audience" $(1875$, no. 2,105$)$.

\footnotetext{
56 Sumarokov wrote that "Gedeon is the Russian Fléchier; he is even more colorful than Feofan; it is unfortunate that there was little strength and fire in him, and that for lack of fervor he often filled his sermons with anecdotes and fables, the poor stock of true eloquence. Agreeability, gentleness, subtlety were his traits, and after Feofan, the devastated Russian Parnassus or church, deprived of rhetorical sweetness due to the death of the great archbishop, delighted Russia with this Gedeon, a man of great merit in oratory" (Sumarokov, VI, 281). Sumarokov thus skips over the entire period from Feofan to Gedeon as unproductive, with Gedeon serving as the continuer of the tradition Feofan founded.
} 
These descriptions correspond in large measure to what Gedeon said of himself (and it is possible that they were formulated under the influence of Gedeon's own declarations). In the foreword "To the Reader" he wrote:

The author agrees with the opinion stated in one of Seneca's works that both the one who speaks and the one who listens must have a single intent; that is, one should act and the other be acted upon; one should not try to do anything besides presenting people what one has in mind to say in as intelligible a way as possible. And since among the people there are always some who are simple and unlearned, for whom sermons in high style are difficult or impossible to understand, in order to put one's intentions into action one must necessarily take steps to make one's words easily comprehensible to even the most unlettered of the simple folk (Gedeon Krinovskii, I, foreword, 1.5 verso)

Similar reasoning may be found in Gedeon's admonitions to young priests that he included in the last volume of his sermons. Although there he is concerned with rhetorical structure, he likely also had in mind his own linguistic practice when he wrote:

...Everyone knows how very few Russian authors there are in print in our fatherland that could serve as an example for you, without mentioning that some of those should not only not be imitated by you, the young, but are also hard to understand for mature minds; but here you will find a style without added profundities and frills with which you can bring benefit to the people to whom you have dedicated yourself. I never tried to tether myself overmuch to rhetoric, but where she herself wanted to serve the word of God, I used her... I only regret that so many people keep silent because they are unable to speak eloquently, and so the benefit which the people could get is lost from sermons even though not written in oratorical manner. Others demand several months to prepare for one sermon... Moreover I am not saying that you should not zealously apply yourself to rhetoric... But I do not condone constrained rhetoric, that which in Latin is called affectata; for the moment I can show you the easiest image, until little by little you can ascend higher and to perfection itself. And I further admonish you, that you prefer benefit to the church above that which might come from eloquence. (Gedeon Krinovskii, IV, foreword, 1. $4-4$ verso $)^{57}$

Here Gedeon gives a characteristic appraisal of the earlier (Church Slavonic) literary tradition as "hard to understand," which is directly analogous to Feofan Prokopovich's opinion (§ I-2.1); at the same time, as with Feofan, criticism of the past serves as a natural counterpart to his own innovation.

As is well known, such declarations as Gedeon's were not something new in the history of Russian homiletics (see $\S 0-5$ ). Simeon Polotskii had

See also Gedeon's attack on proponents of rhetoric in relgious oratory in his sermon on the twenty-first week after the Descent of the Holy Spirit (Gedeon Krinovskii, IV, 81). 
called for simplicity (1681, 1. 7 verso), and so had Prokopovich (in his Rhetoric, Spiritual Regulation, and other works; cf. Kochetkova 1974). Summonses such as these, for all their lack of concreteness and indistinct formulation, were in each instance not only connected to a reevaluation of the previous tradition but a reevaluation of the character of its language as well. Indeed in both cases cited above summonses to simplicity contained the rudiments of particular linguistic programs: for Simeon Polotskii this was a rejection of rhetorically embellished and grammatically refined language in favor of unadorned language (a choice between adorned and unadorned within the framework of standard Church Slavonic), while for Prokopovich it was a rejection of standard Church Slavonic in favor of the hybrid variety. Gedeon's declarations also advocated a certain linguistic agenda that indicated a break with previous tradition.

The innovative linguistic character of Gedeon's sermons was first noted by Filaret Gumilevskii, who wrote that "In reference to his language he no longer follows the example of previous preachers but uses the popular tongue, augmenting it with the liturgical; his word endings, inflection, and syntax are all Russian" $(1884,332)$. This switch from hybrid Church Slavonic to Russian was achieved, as in the history of the language of secular writing (§ I-1.1), by excluding from texts those very markers of bookishness which had earlier been introduced to indicate its Church Slavonic character. In the context of rejecting rhetorical complexity, excluding marked Church Slavonic elements may be understood in principle as testimony to their new conceptualization, not as indicators of linguistic register but as elements of an elevated (affected) style. If we accept this point of view, it turns out that Gedeon's linguistic position precisely accords with those of the secular authors of his time ( $\S$ III-1.2), and it is possible that he acted under the influence of their ideas. ${ }^{58}$

58 L. Kjellberg disputes Filaret's opinion, suggesting that Gedeon was not an innovator, but simply developed the trend that Feofan had begun, the gradual replacement of Church Slavonic with Russian; in Kjellberg's opinion, this replacement was motivated by the rejection of Baroque and the corresponding stylistic simplification (see Kjellberg 1957, 43). [...] As discussed earlier, in my opinion Kjellberg does not distinguish markers relevant for the opposition between Russian and Church Slavonic from those that allow free variation in both Russian and Church Slavonic texts. Filaret Gumilevskii is more sensitive to changes in language, evidently because to some extent he still shared the old linguistic consciousness. The mistaken definition of the type of language in my opinion leads Kjellberg to an incorrect description of the development of the Russian sermon (see his scheme: Kjellberg 1957, 18). The idea that rejecting the Baroque would automatically lead to a gradual replacement of Church Slavonic by Russian also seems incorrect. On the one hand, elements of Baroque style were firmly embedded in Russian religious literature, no matter what the language, and on the other, in Russian linguistic consciousness the switch from Church Slavonic to Russian 
Getting rid of specifically Church Slavonic elements presented special difficulties for religious literature which secular writing did not encounter. In sermons, quotations from Holy Writ cited in the canonic Church Slavonic version were constantly encountered; in sermons in Russian this created a situation of bilingualism, analogous to French sermons which cited the Bible in Latin. Quotations are elements of alien text and do not define the linguistic character of the author's text (hence they were not taken into account in the descriptions of homiletic language analyzed above). However, quotations in Church Slavonic could induce the use of marked Church Slavonic elements in the immediately accompanying text, which could act as a kind of transitional link between authorial and alien speech. ${ }^{59}$ This kind of secondary mechanism needs to be taken into account in describing the language of homiletic literature.

Kjellberg (1957) analyzed the language of Gedeon's sermons in detail and in the analysis below I will rely on his data. The most precise linguistic indicator is the use of the past tense, and here the following picture is observed in Gedeon's writing. In Gedeon's own texts imperfect forms are not used even once. ${ }^{60}$ Instances of the aorist induced by biblical citations are quite common. To them belong first of all the aorist peye used to introduce quoted material (although the form говориль ог сказаль may also perform this function - Kjellberg 1957, 182). There are many other similar cases of induction. Apart from them there are only isolated instances of the aorist; the form бысть occurs several times, and in one sermon the forms согрбиихъ, согрдиихомъ often recur (“Согрђшихъ, прости Господи!," “Согрђшихъ, прости помилуй мя падшаго," etc., ibid, 183). The latter examples are a formulaic response to confession, and the aorist бalcms has special qualities that ensured its preservation in secular literature ( $\S$ III-1.3). Hence we may consider that as grammatical forms the aorist and imperfect are absent in Gedeon's own text. In essence the forms of the past tense with copula are also missing, apart from the separate 2 nd. pers. sg. form used to address

could not be gradual, but presumed a sharp break in linguistic and cultural positions that was revolutionary in character.

59 A prime example of this may be seen in Amvrosii Iushkevich's sermon analyzed above. Here the quoted text induces the use of the 1st pers. sg. pronoun аз: “Сам Бог к Давиду глаголет: аз помазах тя на царство во Израили. Рассудите сия словеса божия, говорит

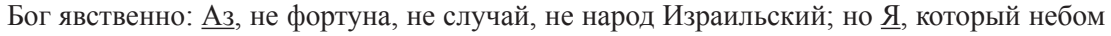
и землею владею...” (Amvrosii Iushkevich 1741, 10).

${ }^{60}$ As the single example of imperfect in Gedeon Kjellberg cites the phrase: "Хрїсту нашему тако подобаше пострадати" (Gedeon Krinovskii, I, 261). However, this is an almost direct quotation from the Gospel: "И тако подобаше пострадати Христу” (Luke 24: 46, cf. Luke 24: 26), so in this case we are not dealing with Gedeon's own text. 
God, where it has the special function of signaling prayer (ibid, 184). Active participles of the type грядый, распныйся are used rarely, as a rule only in paraphrases of Biblical expressions (ibid, 192-3). Hence the entire system of marked Church Slavonic elements is absent, which allows us to regard the language of Gedeon's sermons as Russian.

It is hard to say to what extent Gedeon conceived of all the linguistic factors that were involved in the switch from Church Slavonic to Russian. For linguistic consciousness of the middle-eighteenth century the opposition between the two languages probably looked less clear and precise than it had at the start of the century; one possible factor was the affirmation of the "Slavenosossiiskii" language of secular culture, and the assertion that it shared a single nature with Church Slavonic (§ III-1.2). Significantly, in the first edition of his sermons Gedeon could use constructions with single negation that functioned as markers of the bookish language at the start of the century (see Zhivov 1986b, 252). These constructions were eliminated in the second edition (Kjellberg 1957, 76), i.e., the negative particle was added before the verb, which very much recalls Sofrinii Likhud's corrections to the General Geography (§ I-1.3). Kjellberg cites such examples as "что ни самъ Сатана дълаеть I 95 /не дълаеть 107v," “ничто больше сльдуеть II 162 / не сльдуеть" (Kjellberg cites the changes to the second edition in italics after the back slash). This suggests that Gedeon only gradually became aware of the significance of single negation that led to their removal from the second edition.

Having gotten rid of marked Church Slavonic elements, Gedeon at first apparently thought that he had accomplished his task, and that he had created sermons in Russian. In the first edition of his sermons, the same kind of variability of non-relevant markers as had distinguished the first texts in "simple" Russian (§ II-1) may be observed. Gedeon's language would seem to have needed to undergo the same whole process of normalization as had the secular literary language from the 1730's through the mid-1750's. Thus in noun declensions the gen. and loc. sg. in $-y /-\wp$ is used unsystematically (Kjellberg 1957, 119); in the nom. - acc. neut. pl. the endings $-a /-r$ and $-b l /-u$ (права - правы) alternate (ibid, 122-3); and in the dat., instr., and loc. pl. a confused mixture of endings in $-o M /-e M,-b l /-u /-b l м u,-b x b /-e x b$, and -амъ/-ямъ, -ами/-ями, -ахъ/-яхъ may be observed (ibid, 126-31). In adjectival declensions, nom. and acc. masc. sg. endings vary as -oŭ and -biŭ (ibid, 136-37); in masc. and neut. gen sg. the ending -ова is occasionally encountered (with -аго/-яго dominating; ibid, 138-9); in gen. sg. fem. the endings -оц̆/-ей and -ьıя/-ия alternate (with the former predominating; ibid, 140); and there is a complete jumble of nom.-acc. pl. endings (ibid, 145-50). 
There are also variations in: the pronouns мене, тебе, себе/меня, тебя себя (ibid, 171), present tense $2^{\text {nd }}$ per. sg. endings (-mb/-uu; ibid, 180); and in part of infinitive endings (a rare - $-m u$ with most in $-m b$; ibid 188).

The first edition of Gedeon's sermons was published by the Academy typography (in the civic script) in 1755-59, and the second by the Moscow Synodal typography in 1760 . For the republication the texts were revised in a particular way, and we may assume that this was done consciously either by Gedeon himself or on his direct instructions (see Kjellberg 1957, 80-1) ${ }^{61}$ This revision included the following changes. In nom. pl. of the o- declension the ending $-u$, which appears in rare cases, is replaced by $-b l$; in the nom. -acc. neut. pl. the ending -bl, which sometimes appeared in the first edition, was in many cases replaced by $-a$, and in the dat. and loc. pl. the endings -ovъ/-evr and $-b x b /-e x z$ were mostly replaced by $-a м b /-я м z,-a x b /-я x b$ (ibid, 74). In gen. sg. fem. adjectives, -oŭ was largely replaced by -blя, and nom.-acc. pl. endings have been normalized with the ending -blu virtually eliminated (ibid, 74, 151). The pronouns мене, тебе, себе have as a rule been replaced by the forms меня, тебя, себя; and in many cases infinitives in -ти have been replaced by those in -mb (ibid, 74-5). The intent of these changes is unquestionable: the variable forms were being regularized, and moreover according to the norms of the secular literary language (cf. Koporskii 1960, 126). In this way the language of sermons was to a significant extent merging with that of secular literature, and leading to the formation of a single literary language for both religious and secular writing.

In subsequent years the process continued to develop further. Two eminent church figures of Catherine's epoch, Gavriil Petrov and Platon Levshin, who had advanced thanks to Gedeon's support, carried on his work. Their sermons, written in Russian, set the tone for all homiletic literature. They served as the model which was sanctioned as virtually compulsory with the publication of the Collection of Various Sermons for All Sundays and Holidays in 1775. These sermons had to be read in every church except if the pastor was giving a sermon himself. It is obvious, however, that even if a clergyman decided to juxtapose his own creation to those approved by the Synod he would still be following the norm they had set. This norm related to language as well as subject matter.

${ }_{61}$ The hypothesis that Gedeon himself did the editing (see Kjellberg 1957, 80-1) has some support in the errata lists that accompany the third and fourth volumes of the first edition. Here we find in particular the correction of о талантьхъ to о талантахъ, утьшени to утьшены, and мали and зли to малы and злы, which correspond to the changes incorporated into the second edition. 
In fact the Collection of Various Sermons had been created to make moral admonitions efficacious, clear and comprehensible, and its appearance meant that the old religious didactic literature was now being declared ineffective and obscure (the very same idea which Feofan Prokopovich had propounded in the Spiritual Regulation when he had declared the Slavonic translations of Chrysostom and Feofilakt Bolgarskii to be incomprehensible see $\S \mathrm{I}-2.1$ ). From the point of view of the compilers of the collection, this incomprehensibly stemmed in particular from the Church Slavonic language. It followed from this that if one wanted to speak and be understood, one had to speak Russian. In the foreword to the collection, written in the name of the Synod, the authors rejected the practice that "admonitions (poucheniia) from the Holy Fathers and lives of the saints from prologues, menologions for reading, and [selections] from other books of exhortations are read in church, which they say are sufficient for instructing any person" (Gavriil and Platon, I, 1.3). Echoing Feofan, the compilers counter that "the exhortations of the Holy Fathers and those contained in the books cited, although they do contain moral admonitions, are limited, and not fully complete... besides that they are unclear (temny) in some places, made worse by not very good translation, and their obscurity is also increased by the Slavonic style, and therefore unintelligible not only to simple folk but sometimes also to the educated, or, if they are somewhat comprehensible, then because of their ancient style and lack of clarity, as well as sometimes their length, not very pleasurable or persuasive" (ibid, 1.3 verso; the last two epithets were standard requirements of oratory as defined by rhetorical manuals: "delectare et persuadere"). Having justified the rejection of traditional religious literature, the compilers continue: "Hence it was decided as useful and necessary to supply God's church with new sermons which would contain teachings concerning all the responsibilities of a true Christian and good citizen, and that this teaching be presented in a clear style, and hence intelligible to all, clearly organized, and so able to be long preserved in memory, and at the same time pleasant and full of sweet speech (sladkorechie) as befits the holiness of church, and for these reasons not boring but pleasurable and persuasive" (ibid, 1.3 verso).

In the majority of sermons included in the collection, this program is expressed by the rejection of marked Church Slavonic elements, at the same time as there is a definite normalization of those markers not relevant for the juxtaposition of Russian and Church Slavonic, the principles of which were similar to those on which the normalization of the secular literary language was based. However the language of the collection is not fully homogeneous, which clearly reflects the variety of sources which the compilers used. The collection contains works by Gavriil, Platon, and Gedeon Krinovskii, i.e., 
authors who had replaced Church Slavonic with Russian in their sermons. No other Russian authors are included. A series of sermons are translations and reworkings of Western preachers - Saurin, Bourdaloue, Mosheim and Gesner. From patristic literature only the sermons of John Chrysostom were selected. Still another source was The Stumbling Block by Il'ia Miniat (Elias Miniates), a Greek religious writer of the late seventeenth-early eighteenth century. "By number of works included the first place among all authors belongs to Platon. The selection, changes, reworking, and editing belong to Gavriil" (Sukhomlinov, I, 112). Indeed, all of the sermons were subject to shortening and revision, so that in a literary sense they have a certain unity. For example, in revising Gedeon Krinovskii's sermons, Gavriil typically removes his frequent amusing exempla, leaving mostly fragments containing moral exhortations. The prominence of supra-confessional moralizing is underscored by the inclusion in the Collection of non-Slavic (primarily Protestant) authors, and to a great extent Mosheim's Sermons (Heilige Reden) of 1765 served as the rhetorical model. All of this indicates that the repudiation of the Church Slavonic linguistic tradition was directly linked to the rejection of traditional models of Orthodox homiletics (for example, the works of Efrem the Syrian, Gregory the Theologian, and John of Damscus). ${ }^{62}$

In the absolute majority of texts the language leaves no doubt that this is the Russian literary language of the mid-eighteenth century, into which are interspersed citations from Holy Writ in Church Slavonic. Isolated texts, however, constitute exceptions. Such are the two sermons for Easter (Gavriil and Platon, I, 1. 98-101 verso). In these works, especially the first, marked Church Slavonic elements are quite numerous. On the one hand, their use is based upon the listeners' close familiarity with the Easter service, and on the other emphasizes the special festive nature of the holiday, its exceptionality. Aorists and imperfectives are offered to listeners as magnificent and unusual embellishments, and one may see in this a special kind of transformation of the notion of marked Church Slavonic elements indicating an especially elevated style which was formulated during the creation of the "slavenorossiiskii" literary language (see $\S$ III-1.2). ${ }^{63}$ Significantly, in all

62 Indeed the basic goal of the collection was not introducing people to the holy life of the church but to provide rational enlightenment and instruction. It was asserted that "the ignorance of God's law is the reason for all of the improprieties and abuses in any office," together with the "superstitions" that "shame our faith." It is specifically ignorance and not primal sin or human attraction to evil that destroys the divine order and results in "undermining the general good," "destroying social tranquility and well-being" (Gavriil and Platon, I, 1.2). Clearly, Enlightenment ideals of social harmonly are apparent under the outward form of Christian phraseology and "God's law" serves as equivalent to the prescriptions of reason.

63 The use of simple preterits in the Easter sermons (especially the first one, in which there are a great number, so that they can't be seen as a chance deviation from the norm) is connected 
other sermons, including those for Christmas, simple preterits are absent. For determining the status of marked Church Slavonic elements in the Collection as a whole, it is indicative that in preparing it for publication Gavriil would have eliminated simple preterits from the texts he was editing. Thus, revising John Chrysostom's sermon for the last Sunday before the Great Fast (Syropustnaia nedelia), among other changes the following were included: "...иже между древними проки столпы <быша> были, они хотя и по иннымъ добродЂтелемъ славны и знамениты <быша> были" (RNB, Sobr. Peterburgskoi dukhovnoi akademii, no. 99, 1.55 verso). Thus a text without simple preterits is normal. In this way marked Church Slavonic elements go from serving as an indicator of linguistic register to become markers of style.

The shift from Church Slavonic to Russian was not only limited to sermons, but gradually spread to other genres of religious literature. In 1765 Platon Levshin's Orthodox Doctrine was published (at that time he was still a hieromonk and tutor of religion to Grand Prince Pavel Petrovich) (Platon Levshin 1765). Its short presentation of Orthodoxy's dogmatic theology was written in the Russian language, quite close in its features to the language of Gedeon Krinovskii's sermons. In 1766 Platon's translation of John Chrysostom's sermons (besedy) about the Book of Genesis was published. In the foreword to this edition it says that "In this translation we did not use Slavonic language at all so that our translation would not be obscure and incomprehensible to many people; we judged it better to retreat a little from the venerable Slavonic tongue of ancient times so as to create the least possible obstacle for readers to receive the desired benefit. But neither is there in this translation vulgar speech (vygovor prostonarodnyi), which would have been an unnecessary deviation from the respectful antiquity of Slavonic and a degrading to this holy book's contents" (Ioann Zlatoust I: foreword, 1. 4). Analysis of the foreword itself reveals the wide use of lexical Slavonicisms combined with an absence of marked Church Slavonic grammatical elements. This compromise is what Platon had in mind when he spoke of rejecting "vulgar speech" - apparently, that the language of the translation will emulate the model established in secular literature by Lomonosov and Trediakovskii. This translation not only consolidated the Russian language's hold on sermons by sanctioning it for reading (rather

with their special rhetorical structure that is based on the structure of the Easter canon. [...] The antonymic structure of the canon is repeated in the section of the sermon that contains the main group of aorists (Gavrill and Platon, I, 98 verso -99). It is this specific rhetorical structure that permits us to speak of the special stylistic use of simple preterits within the framework of the new type of literary language that the collection as a whole represents. 
than declamation - the foreword suggests that the sermons be read in church during the Great Fast - ibid), but established it as the language for translations of patristic literature.

It is interesting to note that in this case the rejection of Church Slavonic is not only justified by reference to its "obscurity" but also to the "false rhetoric" of vainglorious preachers. Thus the entire complex of ideas that had taken shape during Feofan Prokopovich's battle with his enemies ( $\S$ I-1.2) and then reflected in Gedeon Krinovskii (see above) was recycled for another epoch. Indeed, Platon writes in the foreword about preachers who seek

to give the audience an inflated opinion of themselves with their oratory. Those preachers do themselves dishonor who even in the holiest place do not abandon this passion, but pile word upon word, adorning their speech with various little flourishes, ignoring the importance and solidity of the truth, not speaking out of the emotion which divine zeal inspires in a Christian teacher but flattering themselves with the idea of being accorded the title of sweet-tongued from some listeners. However, such words grow cold on the lips of this sort of preacher, who themselves, not possessing the inner holy fire, are unable to inflame the listener. (Ioann Zlatoust, I, foreword, 1.1 verso -2)

This empty use of rhetoric is contrasted to the language of Chrysostom himself:

...the style of his speech was smooth, clear, humble, penetrating, pleasant, the most natural, with nothing forced, no empty inflated words, no overly clever oratory, only the power of things themselves, producing the ordered connection of truth... He was very fortunate in coming up with an assortment of comparisons which brought vitality, appeal and concreteness to his speech, and truly there was in him that which is considered characteristic of a great orator, that is, he appealed to both the educated and the simple, was understood by both, and praised by both. (Ibid, 1.2 verso)

The given publication could have served as a model of this style. Thus "in 1770 the Holy Synod instructed the rector Ilarion and prefect Il'inskii to review and revise the translation of Basil the Great's sermons, made in Moscow by the hieromonk Sofronii Mladenovich. They were directed to make the revision 'as clear and precise as possible, i.e., not in lofty Slavonic but in the purest Russian style, and as far as possible to make it similar to the translation of the published conversations of John Chrysostom on the Book of Genesis,' that is, Platon's translation was presented to the editors as a model" (Smirnov 1867, 358). In 1792 selected sermons of Chrysostom came out in Russian translation by the priest Ivan Ivanov (Ioann Zlatoust 1792), also following the model laid down by Platon. The translation was 
evidently also ascribed to the priest Ioann Sidorovskii, member of the Russian Academy, whose translations were sometimes confused with those by Ivanov (Sukhomlinov, I, 271), although it is indeed possible that he took some part in it. The following epitaph was carved on Sidorovskii's gravestone (Sukhomlinov, I, 273):

\section{Течение Иоанн окончил Сидоровский \\ Кой в церкви расплодил язык славеноросский; \\ Чем древле Златоуст во Греции гремел, \\ Он сделал чтобы росс легко то разумел...}

(The course of Ioann Sidorovskii's [life] has come to an end; he made the Slavenosossiiskii language fruitful in the church; that which Chrysostom thundered in Greece of old he made clearly understood to Russians...)

This gravestone inscription ascribes the Chrysostom translation to Sidorovskii and connects the growing use of Slavenorossiiskii in church literature to this work. Whether justified or not, it is notable that Church Slavonic (the language from which Chrysostom was translated) is understood to be inaccessible and that the Slavenorossiiskii language is for that reason welcomed for religious writing. Thus the same scheme as laid out as official Synod policy in the foreword to the Collection of Various Sermons of 1775 is here presented in abbreviated form.

The reform of religious language also extended to hagiography. In 1782 Platon published the "Life of St. Sergius of Radonezh" which he had compiled; although marked Church Slavonic elements were not all excluded from this work (cf., for example, the occasional use of the aorist: Сергїй родися, сотвори прильжную молитву, даде ему часть просфоры Platon Levshin 1782, 3 and 6 verso), their use was motivated by stylistic needs and they were perceived as isolated elevated elements which had happened into a text written in the usual literary language; only symbolic traces were left of the traditional hagiographical language.

One could multiply such examples. The "Slavenorossiiskii" literary language gradually forced Church Slavonic out of all branches of religious literature, so that the use of Church Slavonic was reduced to the liturgy alone. This made the question of translating Holy Writ into Russian (for reading rather than for church service books) an actual one. In 1794 a Russian translation of Paul's Epistle to the Romans was published, the work of Mefodii Smirnov (see Uspenskii 1983, 100), and with the founding of the Russian Bible Society in 1812 work on a systematic translation of the Bible began. The Western model of a single polyfunctional literary language 
triumphed over the bilingualism of civic and church idioms which had arisen as a result of Petrine cultural and linguistic policy.

\subsection{The Unified Language of a Unified Culture}

The synthesis of Russian and Church Slavonic in "Slavenorossiiskii" and the spread of this one language into all branches of writing reflected a new view of literature. The opposition between religious and secular here, as in the language, lost its relevance. In Catherine's reign literary activity acquired the status of something of state importance in which the empress herself took part. Having acquired this status, literature as well as language began to embody the hegemonic character of the regnant culture, not only in intent but in actual functioning, dominating over all speheres of social life. In consequence, literature was also perceived as a unified whole, generating a system of genres in which sermons and theological tracts occupied their own place along with odes, elegies, and comic operas. Describing the styles (shtili) which may be distinguished "in deciding the places for which words are proposed," Amvrosii Serebrennikov in his Russian Oratory lists the styles of: "the church, or didactic [style], [and those of] the court, the courts, school, theater" (Amvrosii Serebrennikov 1778, 158). The principles of constructing speech and models for imitation vary according to venue, but these differences do not prevent the unity of "Russian oratory."

This new unity of literature was manifested in many ways. In 1743, Trediakovskii, trying to receive the place of professor of eloquence in the Academy of Sciences but despairing of getting it from the Academy's conference, asked that the members of the Synod attest to his "abilities in eloquence, in Latin as well as Russian," and was given a statement that "his works are clearly produced according to the precise rules of eloquence, adorned with pure, select words, so that from all this it is clear that he has advanced in eloquence, that is, in Russian and Latin oratory, not just a little but to such an extent that genuine mastery should be credited to him" (Pekarskii, IA, II, 100). Trediakovskii received the position, but not by appointment through the Academy but by the Senate (ibid, 107); the Synod's recommendation was perceived as external interference, and Trediakovskii remained an outsider. Trediakovskii's attempt to publish his Feoptiia and verse paraphrase of the Psalter in the Synodal typography and with the Synod's approval encountered even more resistance; evidently M. Kheraskov, not wanting to acknowledge the religious authority's power over literature, played some part in this 
(Shishkin 1989). Religious literature was perceived as a special sphere that did not have a direct relationship to secular literature, and religious writers as a separate fraternity living its own life and not capable of making judgments about the new literature.

During Catherine's reign the situation fundamentally changed. In 1783 the Russian Academy was founded, and its members included church figures as well as secular ones, and were gathered together as representatives of a single literature, moved by a common desire to perfect the verbal arts. They were occupied by one labor which was for the good of all literature, no matter whether secular or religious. The Academy's first task was the Dictionary, and in line with the established view on literature and the literary language Holy Writ and the liturgy as well as other works by religious and secular authors served as sources for it (see Sukhomlinov, VIII, 19-44). Hence the religious literary tradition became a model together with the secular. After asserting in the foreword that "the Slavenorossiiskii language mostly consists of Slavonic, or to put it more clearly, has its basis in it," the compilers note that to distinguish styles (slogi) the dictionary cites examples from "Slavenorossiiskii, that is, from religious books and from those of the best secular writers, according to which their usage in lofty and beautiful style is defined" (SAR, I, vi, xiv). This combining of church and secular sources influenced not only lexographical work but the literary process itself.

Given the importance of imitation as a category of Renaissance and post-Renaissance poetics, the choice of models came in large measure to define the character of literary creation. Therefore lists of model authors and works emerged as important indicators both of a literature's direction and that of its literary language. The list contained in V. S. Podshivalov's Abbreviated Course of Russian Style, for example, is remarkable:

As regards the reading of good books which may aid in gaining a fundamental knowledge of the Russian language, among these are considered the works of Lomonosov, Feofan, Gedeon, Platon, and St. Dimitrii, and especially his Menalogion for Reading, or his Lives of the Holy Fathers, for prose; and for poetry also those of Lomonosov, Kheraskov, Maikov, Sumarokov, and other most recent ones like Derzhavin, Kniazhnin, Dmitriev, Bogdanovich, etc. After these works follow good translations, as are considered Bielfeld's political admonitions, Cyrus' travels, the Destruction of the Peruvian Empire, the Life of Egypitan Tsar Sif (sethos), the first volumes of Cleveland, passionate Roland, the Life of Marquis $G^{*} \ldots$ and many others, among which the main place is taken by translations from Greek of the whole circle of church [books], that is, the Bible or Holy Writ, ... Chrysostom's sermons, the Margarit, Irmologion, etc. (Podshivalov 1796: 32-33). 
However Podshivalov's personal tastes influenced this list, the very combination of Gedeon and Lomonosov, the Bible and the first volumes of Cleveland (Abbé Prévost), is sufficiently eloquent testimony to the conception of a unified literature. One may find similar lists in Amvrosii Serebrennikov's Russian Oratory and a whole series of other works. Serebrennikov, it is true, gives his list of recommended literature according to "styles" (types of literature), and for this reason does not offer that sort of motley flood of names and titles as we find in Podshivalov. However, here too we do find a similar simultaneous orientation on secular and religious texts. For example, speaking of models of "the philosophical style," he writes: "In this type of writing especially worthy of emulation are the Right Rev. Gavriil, Archbishop of Novgorod and St. Petersburg and the Right Rev. Platon, Archb. of Moscow for sermons, Mr. Lomonosov for public speeches" (Amvrosii Serebrennikov 1778, 157-8).

No less remarkable a discussion may be found in Damaskin SemenovRudnev in the foreword to the edition of Lomonosov that he edited. He repeats the scheme explaining the formation of Slavenorossiiskii's abundance that derives from Lomonosov and Trediakovskii (§ III-2.1), but supplements it with thoughts about the relationship between secular and religious writing:

Our Slavenorossiisikii language also had the fortune to acquire its well-being, abundance and solemnity first from Greek, and then from Greek and Latin. Until today's eighteenth century only Greek books that were needed for the church service were translated and printed, as well as the Bible, saints lives, and the famous works of the teachers of the eastern church. Later also appeared some translations of some Latin writers. By the medium of these translations almost all of the splendor, magnificence, abundance and solemnity of the Greek church language transferred into our language. But the most ancient authors who wrote with splendid taste, that is, Homer, Pindar, Isocrates, Demosthenes, of the Greeks, and Cicero, Livy, Virgil, Ovid of the Latins, - their beauty and tenderness were not yet communicated to it. Then our most wise monarch Great Catherine the Second... noticing [this], was pleased to allot a rather large sum of money as a reward for translations... Since that time have appeared and are today appearing very many excellent books, translated from contemporary European languages as well as from Greek and Latin. But it is unfortunate that many of those who have translated these books have read few or no church books, which is evident from their strange spelling and the composition of their words; and they especially did not take into consideration those writers who out of all of our enlightened society are considered the most skillful stylists. Among these writers the late Mikhail Vasil'evich Lomonosov rightfully occupies the first place. He was quite adept at Greek and Latin as well as several modern languages, and moreover read the church books that had been translated from Greek diligently, and so improved and enriched his speech so that one cannot help but consider him an exemplary author. (Lomonosov 1778, I, 1. 4-5) 
Damaskin Semenov-Rudnev thus not only simultaneously declares the Bible and Lomonosov's works to be normative, but this synthesis of the religious and secular also extends to Greek and Latin literature, in which, in his opinion, patristic works should be supplemented with Homer, Pindar, Virgil and Ovid. ${ }^{64}$

The conception of a unified literature was based on the Western model and conferred upon the new literary language that universality which it lacked as a consequence of the specific nature of Petrine cultural politics which had segregated civil and religious speech (§ III-1.1). At the French academy learned abbots attended meetings together with secular men of letters, and their works merged into one literary process; the sermons of Bossuet and Bourdaloue were considered equally good models of French as Jean-Baptiste Rousseau's odes or Racine's plays. The switch to writing sermons in Russian brought Russia closer to this ideal, as was indeed thought by contemporaries. Sumarokov wrote a special article "On Russian Religious Oratory," and the very fact that he did so is extremely significant, because it marked the unconditional inclusion of religious oratory into the diapason of Russian letters. When giving his short characteristics of individual Russian preachers (whose ranks are completely predictable: Feofan Prokopovich, Gedeon Krinovskii, Gavriil Petrov, and Platon Levshin), Sumarokov directly relates them to Western authors. He writes of Feofan, "This great rhetorician is the Russian Cicero" (Sumarokov, VI, 280); the reference to a Latin author evidently means that Feofan is situated as it were on the border between old and new literature. Further, Gedeon "is the Russian Fléchier" and Platon "the Russian Bourdaloue" (ibid, 281 and 283).

In and of itself the transfer of French concepts and titles is a regular feature of eighteenth-century Russian literary thinking; hence Lomonosov was considered in his time "the Russian Malherbe" and Sumarokov "the Russian Racine." Including famous church orators in this pattern indicated that Russian letters had achieved the same fullness as French. Significantly, this achievement was in one way or another connected with writing sermons in Russian: "Slavenorossiiskii" thus achieved the polyfunctionalism characteristic of the French literary language (§ III-1.1). Sumarokov's disciple F. G. Karin wrote directly about this:

\footnotetext{
$\overline{64}$ It is precisely this synthetic approach, and by to means some sort of undivided cultural consciousness, smoothly moving "from ascetic sto sinful passions" and "from Christian miracle to miraculous adventures" (as Hans Rothe suggests — Rothe 1984, 94) that explains the desire to unite disparate spheres in search of the sources for the new culture, as well as sources of purity for the new literary language.
} 
Feofan was the first who departed from the Slavonic linguistic prototype (pervoobraznost'); to do this he introduced everyday usage, so that given the harmony of his expressions, which reflect everything touching his thoughts or the content of his sermon as if in a mirror, he would be understood by everyone... We are indebted to him for the fruitful issue that we have produced, our own Bossuets, Fléchiers, and Massillons. Today our church pulpit does not yield place to any one of the holy pulpits in Europe, and has risen to such a degree of perfection as could only be desired. (Karin 1778, 6)

The unity of letters presupposed a unity of stylistic criteria. In the second half of the eighteenth century, secular writers could judge the stylistics of religious literature, applying the same precepts as in secular literature; religious writers could equally draw up their own prescriptions for all of Russian literature, relying on the theories worked out in the midcentury polemics over language. Hence Sumarokov in the article cited above wrote that "I see in Church Orators my brethren in rhetoric alone, and not in holiness; and so I have a right to speak about them, just as much as they have a right to speak about me, insofar as such mutual judgments belong to those who admire literature" (Sumarokov, VI, 277). At the same time Sumarokov criticizes Baroque sermons, approaching them with the Classicist demands for naturalness and comprehensibility, and addressing the same complaints about them as those he had made, for example, about Lomonosov's odes:

Many religious orators who have no taste do not allow either their heart or their natural understanding into their works, but, intellectualizing without basis, imagining indistinctly, and hoping for the usual praise of the mob (which goes into raptures over everything it doesn't understand), dare to make their way to Parnassus up crooked paths, and instead of Pegasus bridle a wild stallion, or sometimes an ass, and are pulled up a crooked road onto some sort of hillock where not only the Muses but their names have never been heard of, and instead of fragrant narcissus they gather dandelions. (ibid, 279)

In relation to religious oratory Sumarokov expresses his habitual complaint — natural in the context of his Classicism — against "inflated sentences ornate beyond measure, neither in agreement with mind nor heart" (ibid, 280). Characterizing Gedeon's sermons, Sumarokov points to their "pleasantness, tenderness, subtlety" (ibid, 281), and here he obviously has in mind linguistic considerations analogous to those he defines for secular authors using the same terms.

To understand this process the attitude toward Prokopovich which came into being during this period is instructive. As we have seen from the material cited above, Prokopovich was put forward as one of the new model authors, and was often named along with Kantemir and Lomonosov as father 
of the new Russian literature. Both the association between Prokopovich's sermons and the Petrine cultural policy which had brought about the new literature as well as the conception of a unified literature, in which his sermons took equal place alongside Lomonosov's odes, evidently influenced this view. At the same time the hybrid Church Slavonic in which Feofan wrote was reconceptualized, and could now be perceived as "Slavenorossiiskii," which could include a large quantity of marked Church Slavonic elements. However it was quite impossible to reclaim this language under the criteria of Classicist purity, and for this reason tributes to Feofan are almost always accompanied by complaints about his impure language. This ambiguity may be traced as far back as Lomonosov, who removed words of praise for Feofan as an orator from his Rhetoric (see Lomonosov, VII², 174); it is assumed that he did this because he did not want "to make an example of an author who did not observe "purity of style"" (Kochetkova 1974, 65; cf. Lomonosov, VII $\left.{ }^{2}, 821\right)$. On Lomonosov's advice Sumarokov also excluded a positive reference to Feofan from his "Epistle on the Russian Language" of 1748, apparently for the same reasons. ${ }^{65}$ The excised section contained both a comparison of Feofan to Cicero and a remark about the impurity of his language

Последователь сей пресладка Цицерона

И красноречия Российскаго корона.

Хоть в чистом слоге он и часто погрешал;

Но красноречия премного показал.

Он Ритор из числа во всей Европе главных, Как Мосгейм, Бурдалу, между мужей преславных.

(Grinberg and Uspenskii 1992, 223, Lomonosov VII²: 821)

(This [was] a follower of sweet-tongued Cicero and crown of Russian oratory. Although he often sinned with impure style, he demonstrated great eloquence. [He was] among the best rhetoricians in all of Europe, along with the most famous men like Mosheim and Bourdaloue.)

What these defects were Sumarokov explained later: "Ukrainian turns of speech and foreign words which were required for some unknown reason

65 This is suggested by the commentators to the second academic edition of Lomonosov (Lomonosov, VII ${ }^{2}, 813,821$ ). M. S. Grinberg and B. A. Uspenskii note that there is no documentary evidence of this interference and hypothesize that it was sooner the result of "a tactical ruse" by Sumarokov, who succeded in having the epistles published by the Academy of Sciences (Grinberg and Uspenskii 1992, 224). In any case, Lomonosov and Sumarokov held the same opinion of Feofan's style that fit their overall theoretical position. 
somewhat disfigured his works; but they were quite made up for by another sort of purity" (Sumarokov, VI, 280).

We may also cite S. F. Nakoval'nin's assessment in the foreword to Feofan's Sermons and Speeches:

If someone would want to diminish his honor, [saying] that he employed an uneven style in his sermons, mixing in Slavonic, which was the basis of his writings, and sometimes popular expressions and sometimes language not used in Great Russia; then first of all one may easily answer along with Cicero and Horace that use by intelligent men does honor even to vulgar speech, and secondly, that he may be excused because he was occupied by many most important affairs and did not have the time to delve into all of the subtleties and beauty of language. (Feofan Prokopovich, I, foreword, 1. 2-3)

A. S. Shishkov later gave Feofan a similar evaluation: "His Slavonic style, sometimes mixed with popular turns of phrase, could in some places have been more even and pure, but these are trifles not noticed in great creations... They do not interfere with our appreciating his great merits, which consist in the order and depth of his thought, in the fecundity of his imagination, the appropriateness of his embellishments and power of his language" (Shishkov 1813, 9-10). Karamzin has a similar remark about Feofan. He calls him a "natural born orator" but nonetheless asserts that "in his speeches, both secular and religious, are strewn a multitude of the flowers of eloquence, although their style is impure, and one may say, unpleasant" (Karamzin, I, 574). The similarity of Karamzin's and Shishkov's views is very striking ( $(I V-1)$, and demonstrates that for purism of any type the very idea of hybrid language is unacceptable. At the same time, we see here a convergence of purist conceptions which derive from Classicist linguistic doctrine which did not lose its force even though these conceptions were diametrically opposed to one another.

The unanimity of stylistic criteria as applied to both secular and religious wrtings guaranteed the interaction of linguistic practices in these two branches of literary activity. As discussed above (§ III-3.1), in preparing a second edition of his sermons Gedeon Krinovskii carried out a definite normalization of the language (noun and adjective endings, forms of the infinitive), and the principles of this normalization coincided with those that had already been implemented in secular literature. This means that in his linguistic practice he accepted those notions of what was or wasn't normative, pure or impure, that had been worked out by secular philologists who were trying to normalize the "civic tongue." The interaction of stylistic notions may also be seen in the way religious and secular writing made use of simple preterits. As we have seen in the analysis of the sermons for 
Easter included in Gavrill Petrov and Platon Levshin's Collection of Various Sermons for All Sundays and Holidays, simple preterits were a violation of the norm that functioned as a sign of special divine ecstasy. The same thing may be seen in Sumarokov's psalm paraphrases ( $\S$ III-2.2) and in those of several of his followers. It is natural to conclude that this resulted from the mutual influence of secular and religious writing.

Similar lines of development emerge upon analyzing infinitive forms. Although Lomonosov and Trediakovskii rejected the - $m u$ form as nonnormative, other authors continued to use it. This is the case, for example, in Fonvizin's translation of Bitaubé's "Joseph," in which in the translator's opinion "it was necessary to maintain the solemnity of the Slavonic language" (Fonvizin 1769, foreword, 1.1 verso; typically, in the foreword Fonvizin uses infinitives in - $m b$ ). It is also true in M. Popov's translation of Tasso's Jerusalem Liberated (Tasso 1772). Sumarokov also continued to use the - $m u$ form, from somewhat different motives (see $\S$ III-2.2); in his psalm paraphrases, written in free verse, there only occur infinitives in $-m u$, evidently indicating a form absent in conversational usage that therefore denoted inspired prophetic speech. This use of $-m u$ for stylistic purposes is described in A. A. Barsov's Russian Grammar: Barsov writes of the infinitive form: "Its direct and full ending similar to the Slavonic is in $m u$, which now may be used only in verse or in high or church style, but otherwise it is abbreviated as $m b$ " (Barsov 1981, 592). Barsov's mention of "church style" is not accidental; in the religious tradition variation of infitive forms had not been eliminated, which could lead to conceptualizing the - $-m u$ form as one of its specific features, and hence as a stylistic element appropriate to high spiritual thematics. ${ }^{66}$ It is natural to conclude that the stylistic weight of $-m u$ forms in secular literature derives from this practice of religious literature, and in turn that religious writers might have assimilated the view of this form as a stylistuically charged non-normative element; hence this form could appear as we have seen in Gavrill Petrov's Easter sermon, differentiating it from all of the other texts in the Collection of Various Sermons. Thus here too the interaction of the two literary traditions is apparent.

Together with this sort of stylistic equivalence another kind of interaction may be seen, when it is as if the specific linguistic peculiarities

\footnotetext{
${ }_{66}$ The changes that S. Nakoval'nin made to Feofan Prokopovich's texts when they were republished in the 1760's are indicative of this perspective. Nakoval'nin himself, judging by the forword to Prokopovich's Sermons and Speeches, did not himself use the -ти form. In Feofan's sermons, however, in many cases he replaced -ть with -ти forms (e.g., in the sermon on Peter I's burial; compare Feofan Prokopovich 1725 and Feofan Prokopovich, II, 128-32). Nakoval'nin clearly sees the -ти form as characteristic of religious writing, and edits Prokopovich accordinngly.
} 
of the secular and religious literary traditions cancel each other out. Thus in religious literature the old inflections in oblique pl. cases are most rarely met in instr. pl. This tendency is encountered in all homiletic literature from Simeon Polotskii to Gedeon Krinovskii (see note 48 above). This does not involve the changeover from hybrid Church Slavonic to Russian, which emphasizes the fact that the variability of the given endings does not correspond to the opposition between languages but reflects the uncontrollable continuity of linguistic habits. The evolution of the secular language leads to a completely opposite result. Of all the old inflections only the instr. pl. in -bl remained in use; the expressive distinction between the old and new endings in the instr. pl. rendered it significant, a stylistic means which Tatishchev, Trediakovskii and Lomonosov all made use of (cf. Martel 1933, 81; Makeeva 1961, 104). With the merging of religious and secular literature and the creation of a single literary language these opposing peculiarities neutralize each other. In secular literature, starting with Sumarokov and his followers, the instr. pl. in $-b l$ ceases to be used for stylistic reasons, and this leads to the uniform usage of the new endings. The same practice is established in religious literature after Gedeon Krinovskii, as can be seen, for example, in the Collection of Various Sermons. In this way, in cases where there are corresponding yet distinctive traits the interaction between the two traditions leads to the broadening of the stylistic repertoire of the literary language, while in cases where there are opposing features this leads to the smoothing away of differences. It was precisely the result of this kind of process that established a single universal norm for the new literary language in service of one united literature.

The "duality in unity" (dvuedinstvo) of Russian literature which came into being in this way emphasizes the duality in unity of the literary language. The thesis about its combination of Church Slavonic and Russian became a commonplace and was proclaimed as a starting point which needed no special proofs. In the Russian Academy's statutes it is presented almost in passing, as an explanation of the Russian language's special richness: "A language's richness follows plainly from the abundance of words and locutions (phrases), when each thing, each idea or action may be depicted in its own words or locutions. The Russian language may chiefly pride itself on such abundance, being made up of so-to-speak two languages, i.e., the ancient, or Slavonic, and the one derived from it, which is used today" (Sukhomlinov, VIII, 425).

We find analogous reasoning in V. Svetov's article "Several General Notes on the Russian Language": "Starting from the unification of the Slavonic and Russian dialects if we add the words used by Russians during the middle ages that are preserved in ancient chronicles and deeds, 
and if we also demand explanations, what a huge dictionary will some day be compiled!" (Svetov 1779, 82). The issue here, of course, is not merely about compiling a big dictionary, but about the lexical reserves of the literary language which combined both Russian and Slavonic sources. The possibility of this combination and its stylistic parameters are specially defined. The author differentiates between the "Slavonic," "Slavenorossiiskii," and "New Russian" (Novorossiisikoi) languages: "The ancient Slavonic language, that I call dead, was used only in conversation before the invention of writing. After the acquisition of letters the Bible was written in Slavenorossiisikii, as well as chronicles and other handwritten documents; New Russian is justly considered that which educated Russians speak and write today, and had its origin in the time of the Renewer of the Russian Word [i.e., Peter I]" (ibid, 80-1). In making these definitions, the author notes that in the high style New Russian combines with Slavenorossiisikii, and as an example of this he gives "church sermons" as well as "other works" in verse and prose:

However, observing the purity of the New Russian language in ornate works, they [writers] also with reason borrow equivalent phrases from books in Slavenorossiisikii, and thereby beautify their style to no small degree. We see this in the most recent church sermons and in other works written in verse and prose. For in high style works in verse and prose it is most appropriate to preserve ancient Slavenorossiisikii features in place of the new, for example: восходяму солниу на высоту небесную, as opposed to (if in simple language), когда солние восходило оr когда разсвътало; also гнъвъ Божій проліется instead of Богъ прогнъвается; вижу восходящую брани тучу, instead of: се война подымается, and so forth. (ibid, 81)

It is very indicative that the Church Slavonic elements (or what the author considers them to be) are included in the high style while still "observing the purity of the New Russian language." In the framework of the new literary language they are thus defined as "pure" lexical elements par excellence.

In connection with the "dual unity" of the literary language the notion of linguistic purity is also bifurcated. An eloquent example of this may be found in Amvrosii Serebrennikov's Oratory (Oratoriia) (cf. Sukhomlinov, I, 189-98). Amvrosii's handbook may be seen as an eclectic attempt to synthesize various linguistic theories about style which had been developing in eighteenth-century Russia, and thus may serve as a record of the evolution that the linguistic and stylistic theories of French Classicism had undergone in being adapted to the Russian situation.

Oratory openly declares the fundamental principles of Classicist purism, and in Amvrosii's formulations can be heard an echo of Vaugelas, apparently through Trediakovskii's mediation (Sukhomlinov, I, 194). Here 
the necessity of "purity of style" is asserted and usage is indicated as the main criterion: "Purity of style requires pure expressions... Pure expressions," he explains, "are those which 1) are universally approved, 2) comprehensible, and 3) used in important works by our best writers" (Amvrosii Serebrennikov $1778,98)$. In the definition of "universally approved" expressions we find Vaugelas' notion of usage before its characteristic Russian transformation (§ III-2.3): "Universally approved expressions are those which the best people of capital cities use in general conversation" (ibid, 99). This approach had no practical significance, however, and Amvrosii quickly combines usage with the literary tradition, which necessarily served as the real criterion. "But it is less dangerous and more convenient to learn this purity from important works by the best Russian writers. Such are all of Mr. Lomonosov's works, Mr. Sumarokov's and others" (ibid). References to "an educated ear" and "grammatical rules" supplement the assortment of reference points that Amvrosii substitutes for the criteria of usage (§ III-2.3).

Amvrosii's interpretation of linguistic "coarseness" is very indicative. After stating that "coarse expressions harm the purity of style," he goes on to define them, and here it becomes obvious that coarseness is by no means contrasted to refinement of speech or to language practices of the social elite (as it would be in a direct adaption of Vaugelas' doctrine) but grammatical correctness that demanded of a writer not habituation to good society but educational experience. "Coarse speech and expressions," Amvrosii writes, "are those which: 1) are strange to the educated ear, and used only by the simple folk; 2) whose writing is contrary to general speech or to the grammatical rules; and 3) which take pure expressions and create or end them in a new way, for ex., швыряю, that is, бросаю; притча instead of случай; получить убыток, потерять человека instead of убить; презирать кем instead of кого, предвершение, раболепность, and so on" (Amvrosii Serebrennikov 1778, 99-100).

Together with this Amvrosii recognizes the reality of Russian Church Slavonic bilingualism. This recognition of the two languages as independent systems evidently does not seem to be something that he must camouflage by references to their continuity or shared nature. This acceptance of bilingualism may be connected to a new perception of Church Slavonic as the cult language, which in the form of quotes and paraphrases may be freely introduced into Russian texts; as we have seen, this practice had become quite standard for Amvrosii thanks to the newly formed tradition of Russian sermons (§ II-3.1). Hence Amvrosii may write: "We have two languages, Slavonic and Russian, and therefore there may be pure Slavonic turns of phrase unknown in Russian, and conversely Russian ones which sound 
strange in Slavonic. However, since today no one in our country speaks pure Slavonic, which is contained only in Church books, and since Russian is not as abundant and lofty, here and in the following chapters we will have in mind a style combining Slavonic and Russian" (ibid, 98). ${ }^{67}$ This unlimited assimilation of Slavonicisms into the literary language corresponds, as we have seen, to the unification of secular and religious traditions into one literature, and this is directly reflected in Amvrosii's list of models of high style. Here "one should study books by ancient and new writers, such as the holy Greek Fathers, and especially the creators of the canons, the panegyrists; and more than anything else the narratives, songs, psalms, prophecies and moral teachings of Holy Writ; of the Russian writers Mr. Lomon[osov] in odes, Mr. Sumarokov in odes and tragedies..." (ibid, 155).

And so the opposition between worldly and spiritual, secular and clerical, ceased to play any role either in choosing works to imitate or in selecting the very means of expression. In these conditions, Church Slavonic linguistic material is conceived of as neutral, and this was the dominant perception of the period, that is, Lomonosov's interpretion of Slavonicisms ( $§$ III-2.2) was accepted; according to this view Slavonicisms were not specially connected to "elevated" or "rhetorically embellished" speech but functioned as a neutral means of expression which could be used in any genre except those in which they would conflict with specific Russicisms. It was precisely as a result of this reconceptualization that the so-called "Slavenorossiiskii" language developed, a language in which in V. D. Levin's words "the role, place, and function of archaic, 'Slavonic' lexicon... were very significant and were not limited to traditional high genres," or in other words, "high lexicon... was disassociated... from high style" (Levin 1964, 50 and 56; both

67 Corresponding to this mixed character of "pure" vocabulary are the words that make up the rubrics of those which "damage purity." Here in the first place go "coarse expressions" and borrowings, while archaisms are practically absent. Archaisms are included in the more general category of "incomprehensible expressions": "Incomprehensible expressions may be either extremely ancient, newly invented, used in an incorrect (otmennom) meaning, or borrowed from foreign languages, for ex., Тиун, горволь, слана, самостоятельность, шамад, бреш" (Amvrosii Serebrennikov 1778, 100).

Following Lomonosov, Amvrosii normalizes the simultaneous use of Slavonicisms and Russicisms, although characteristically his prescriptions relate not only to the middle style, as in Lomonosov, but to the literary language as a whole (this reflects the interpretation of Slavonicisms as a neutral element — see § III-2.2): "Because our style consists of Slavonic and pure Russian expressions, and these languages are different from each other, one must be careful in choosing [words], so that one does not place a pure Slavonic expression next to a pure Russian one... Because there is nothing more offensive to the ear that this kind of absurd combination, which must be particularly avoided in verse" (ibid, 102; cf. the similar discussion in Rizhskii 1796, 11). 
the epithets "high" and "archaic" are in this context anachronisms: they represent the scholar's value judgements which do not accord with those of the epoch in question).

It is indicative in this connection that Slavonic linguistic material was now seen as naturally corresponding to the "pure" vocabulary of Western European languages which were oriented upon spoken usage, and in this capacity was widely put to use in numerous translations of the period (see Lotman and Uspenskii 1975, 204-207 and 238-39). Moreover Slavonicisms turned out to be directly juxtaposed to borrowings, and were correlated with them as "pure" to "impure" elements, so that the struggle against borrowings and the introduction of Slavonicisms functioned as two sides of one process (in comparison, we may note that the struggle against borrowings in French never led to using archaic lexicon or Latinisms). Church books became not only the ideal measure of the correctness of the Russian literary language but also a practical source for replenishing vocabulary (Trediakovskii may serve as model of this practice, as he justified his neologisms by reference to church books; see § III-1.3). Hence in Amvrosii's handbook referring to church books is directly prescribed: "If something new has been invented, then it is permissible to think up new expressions [to describe it]; but one must be very careful of coming up with a new phrase for something that has long had its own name. Diligent reading of Slavonic church books will do much to avoid this" (Amvrosii Serebrennnikov 1778, 100-1).

This view directly corresponds to M. Popov's well-known remarks that precede his translation of Tasso's Jerusalem Delivered. Noting that he "tried to observe... such a style as was demanded by the weight and dignity of this poem, in which magnificence, love and tenderness reign everywhere" (Tasso 1772, p. S), Popov continues:

In translating such an excellent and difficult work as is this type of poem, it was inevitable that many words were encountered which either we do not have in our language or which we still do not know about because we do not take pains to delve into the vast and rich Slavonic language, which is the source and beauty of Russian, and which over time of course will not yield in abundance to any other language in the world. I too could not avoid facing these difficulties, and could not free myself from them other than searching in religious books or in newly translated ones for words of the same meaning as those which I encountered in French; or I translated completely anew. For a poem will not tolerate foreign words unless unavoidably necessary; but they should not be tolerated anywhere. (Tass 1772, p. i)

Popov further presents an extensive list of his discoveries, in some cases supplying direct references to the Bible, for example: "Catapulte, f.... 
Стрелостоятельница, Macc[abees] B[ook] II, Chap. VI, 1.20:51," “Espion, m. Соглядатай, Мacc[abees] B[ook] II, Chap. V, 1. 38, Созиратель, Chap. XII, 1. 26," “Trophée, m. Bceоружие, Macc[abees] B[ook] II, Chap. XIII, 1. 29" (ibid, p. AIf).

The same conception was also formulated by the translators of Works of the Most Wise Plato, I. Sidorovskii and M. Pakhomov:

In presenting [this material] on the life, type of work and language of this philosopher, we consider it not inappropriate to briefly inform readers about this translation into Russian as well. To some it may appear that the style used in this translation is unsuitable for a style typical of everyday conversation... insofar as they will find a great multitude of expressions more characteristic of oratorical rather than conversational style. The reason for this is that Plato himself used a middle style between that of prose and poetry. Because of this it was necessary to observe a similar style in this translation and to approach somewhat the character of the Slavonic language. In some places we also depended on some expressions borrowed from ancient Slavonic, and some created anew, without however ignoring their own meaning; for in this case we also imitated a writer who similarly borrowed some [expressions] from the ancient Hellenic tongue, and some created anew... (Plato 1780, xii-xiii).

The authors here evidently relied on Trediakovskii's practice, although either directly or indirectly the source of their innovations as translators again turns out to be Holy Writ.

The cultural synthesis of the second half of the eighteenth century thus led to the emergence of a unified literature which embraced both secular and religious works, and also to the development of a single literary language which combined basic principles of Russian and Church Slavonic. Insofar as such a union was openly admitted, the old bookish tradition could freely influence the new writing, and this conditioned the priority of the "Slavonic" component over the "Rossiiskii" in the unified "Slavenorossiiskii" tongue. Corresponding to this development, the conception of the literary language also changed; the purist doctrine of French Classicism transformed into that Slavonicizing and rationalist purism whose theoretical basis had been established in Trediakovskii's and Lomonosov's works, and which thereupon became a commonplace of Russian linguistic thought. The cultural unity created in this way was illusory and fated to a brief existence; with its decline the epoch of "Slavenorossiiskii" was also to come to an end. The new developments produced by this decline will be examined in the following chapter. 